\title{
Los olmecas, Covarrubias y las ideas modernistas sobre el estilo
}

\section{The Olmecs, Covarrubias, and the Modernists Ideas on Style}

Artículo recibido el 22 de abril de 20I8; devuelto para revisión el 22 de noviembre de 2018 ; aceptado el 23 de febrero de 20I9; https://doi.org/IO.2220I/iie.18703062e.2020.Suplemento.2708

Renato González Mello Instituto de Investigaciones Estéticas, Universidad Nacional Autónoma de México, Academia de Artes, mello@unam.mx; https://orcid. org/0000-0002-087I-8426.

Publicación más relevante Coeditor de Elsa Arroyo, Anny Aviram, Miguel Ángel Fernández Delgado, América Juárez, Chris McGlinchey y Sandra Zetina, Baja viscosidad: el nacimiento del fascismo y otras soluciones/Low Viscosity: The Birth of Fascism and Other Solutions (Ciudad de México: Universidad Nacional Autónoma de México-Instituto de Investigaciones Estéticas, 2013); autor de La máquina de pintar: Rivera, Orozco y la invención de un lenguaje emblemas, trofeos y cadáveres (Ciudad de México: Universidad Nacional Autónoma de México-Instituto de Investigaciones Estéticas, 2008).

Resumen El artículo examinará los argumentos de Miguel Covarrubias para postular la existencia de los "olmecas", haciéndose eco de otras investigaciones recientes, atendiendo a tres cuestiones: un argumento iconográfico sobre el lugar del fetiche en medio de la selva, que a su vez remite a las ideas sobre el canibalismo; un argumento sobre el "estilo" que retomó recursos teóricos y pedagógicos en uso en aquel momento en los museos estadounidenses, que Covarrubias conocía bien; finalmente, un argumento de historia social, en el que los "olmecas" serían una élite aristocrática que conquistó a un pueblo de campesinos. A juicio de quien esto escribe, este último argumento puede leerse como un retrato de la sociedad mexicana del siglo xx.

Palabras clave Miguel Covarrubias; olmecas; estilo; Hugo Moedano; arqueología del siglo XX.

Abstract This paper will examine Miguel Covarrubias' arguments to postulate the existence of the "Olmec", echoin recent researches and taking into account three problems: an iconographic argument about the fetish's place the middle of the jungle, which in turns refers to ideas about cannibalism; an argument about style that took theoretical and peda- 
gogical resources used at the time in North American Museums, which Covarrubias was familiar with; finally, an argument of Social History, that considers the Olmec as an aristocratic elite that conquered a peasants' nation. In this author's opinion, this last argument could be considered as a portrait o Mexican society in twentieth century.

Keywords Miguel Covarrubias; Olmec; style; Hugo Moedano; twentieth century archeology. 
DOI: https://doi.org/10.22201/iie.18703062e.2020.Suplemento.2708

RENATO GONZÁLEZ MELLO

INSTITUTO DE INVESTIGACIONES ESTÉTICAS, UNAM

\section{Los olmecas, Covarrubias \\ y las ideas modernistas sobre el estilo}

Para Francesco Pellizzi

\section{Planteamiento}

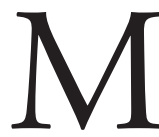

iguel Covarrubias es conocido por sus caricaturas de la vida bohemia en Harlem, por el folklorismo de su obra, por sus dibujos de los mares del sur y por sus teorías arqueológicas. Estos saberes dispares — el arte moderno y el arte antiguo — no fueron reunidos más que muy esporádicamente por otros actores y participantes del movimiento moderno en las artes plásticas. Covarrubias aplicó los principios del análisis formalista, su propia experiencia como dibujante y las ideas más variadas para interpretar realidades tan distantes como el surgimiento de la cultura olmeca y la crisis económica estadounidense. Propongo una reflexión acerca de la invención del estilo olmeca, aunque el debate de los especialistas a veces ha derivado la reflexión y el debate hacia la existencia de ese grupo humano: de los olmecas. Historia del arte y arqueología son gemelos que riñen con cierta frecuencia, pero se parecen bastante. El objetivo de estas líneas es pensar en una articulación concreta de la noción de "estilo". La idea es hacer una suerte de recuento etnográfico de la noción de "estilo" y los distintos cacharros que se utilizaron para invocar semejante ficción. ${ }^{I}$ Huelga decir que el objeto de esta "etnografía"

I. Sería imposible definir cada sustantivo abstracto en un texto, pero estoy obligado a referir 
más bien silvestre no serían los antiguos habitantes de las ciudades selváticas del Golfo de México, sino los modernos intelectuales del altiplano de México en el siglo xx: Miguel Covarrubias, Diego Rivera y Hugo Moedano, así como las mitologías modernas que toman las formas de la historia, la antropología, la arqueología y la historia del arte.

Voy a seguir este proceso intelectual a través de tres herramientas. Por una parte, en una serie iconográfica. En segundo lugar, para poder construir a los olmecas (o si se prefiere, reconstruirlos), fue necesario hacer excavaciones y describirlas. Pero la descripción verbal de los hallazgos, incluso su representación fotográfica, no fueron suficientes. Se requirió de una herramienta más: un diagrama. Lo que propongo es que la noción de "estilo", que aparece muy temprano en este proceso, es una especie de sublimación del simbolismo, si vale la redundancia; que el "estilo" aparece cuando ya no se puede hablar de la raza o el deseo, como lo hacían los literatos y artistas de entre siglos.

Una palabra más: este artículo se refiere al arte y la cultura de la modernidad. En este sentido, los estudios sobre los olmecas, y lo que pudiera decirse sobre aquellas sociedades, escapan al alcance de las reflexiones que aquí se proponen. Son muchos y muy serios los estudios recientes acerca de las sociedades que habitaron la cuenca del Golfo de México durante el periodo preclásico; algunos se citan en la bibliografía de este artículo, pero remito a quien se interese en aquellas sociedades de la antigüedad a lo que aportan los volúmenes recopilados por María Teresa Uriarte con Rebecca González Lauck, y a obras clásicas como las recopilaciones publicadas por Dumbarton Oaks. ${ }^{2}$ Éste es un capítulo relativo a la

\footnotetext{
"ficción" a lo que afirma Jeremy Bentham, Teoría de las ficciones (Barcelona: Marcial Pons, 2005), 66-Ior; Invención se entiende en el sentido de Edmundo O’Gorman, La invención de América: investigación acerca de la estructura histórica del nuevo mundo y del sentido de su devenir (México: Fondo de Cultura Económica, 1992), pero mediado por lo que asegura otro lector de Heidegger: Byung-Chul Han, Hiperculturalidad: cultura y globalización, trad. Florencia Gaillour (Barcelona: Herder, 2018), 65-68. Como O'Gorman, este autor previene de juzgar que los discursos estén completamente articulados en los textos concretos, llama a examinar sus componentes pero, a diferencia de las "mónadas" de Leibniz, considera que esos componentes están abiertos siempre. Para fetiche, me apoyé en la reflexión y los textos recopilados por Cuauhtémoc Medina y Mariana Botey, "En defensa del fetiche", El espectro rojo, Madrid, mayo de 20 o.

2. María Teresa Uriarte, Rebecca B. González Lauck, eds., Olmeca: balance y perspectivas. Memoria de la primera Mesa Redonda (Ciudad de México: Universidad Nacional Autónoma de México-Instituto de Investigaciones Estéticas, 2008); Elizabeth P. Benson, ed., Dumbarton Oaks Conference on the Olmec (Washington: Dumbarton Oaks Research Library and Collection, Trustees for Harvard University, I968); Rebecca B. González Lauck, "La zona del Golfo en el preclásico:
} 
historia moderna y a la historia del arte mexicano. Como tal, de ninguna manera podría explicarse en los términos que son habituales en la historia de la arqueología y la antropología, que suelen enfatizar el debate interno, la formulación de paradigmas y los hallazgos en los términos de los estudios sobre Mesoamérica.

La historia de las ideas sobre los olmecas y Mesoamérica es necesaria, proyectada hacia la actualidad desde la antropología de hoy; pero aquí se expone otra cosa: un capítulo en la historia de la ideología del Estado mexicano. Se trata de hombres y mujeres modernos que vivían en ciudades como Nueva York y México, se ponían saco y corbata, escribían libros, dibujaban, tomaban fotografías y no construían pirámides, pero sí estructuras tangibles e intangibles igual de eficaces (y hermosas). Esto de ninguna manera niega la calidad de su aportación, la necesidad del saber que construyeron, su honestidad, la pertinencia de sus argumentos o la calidad del arte que llamamos "olmeca". Si algo se reivindica en estas líneas es que la de Covarrubias es una historia de las ideas en toda línea y sin cortapisas, aunque hemos procurado evitar la diplomacia y los protocolos elegiacos precisamente por la convicción de que sólo el debate restaura la jerarquía de la historia intelectual.

\section{La serie iconográfica}

"La iconografía", dice Luis Cardoza y Aragón, "lee como pitonisa que se toma en serio". No sería éste el lugar para explorar a fondo los aciertos y limitaciones del método desarrollado a partir de las ideas y práctica de Aby Warburg, ${ }^{4}$ pero en atención a que este artículo mira desde la cultura del siglo xx temas importantes para la arqueología, explico brevemente lo que pretendo con este apartado. Los objetos arqueológicos tuvieron, para Covarrubias, un lugar ambivalente.

la etapa olmeca”, en Historia antigua de México, ed. Linda Manzanilla y Leonardo López Luján, (Ciudad de México: Consejo Nacional para la Cultura y las Artes/Universidad Nacional Autónoma de México/Porrúa, 1994), 279-322.

3. Luis Cardoza y Aragón, El río. Novelas de caballerías (Ciudad de México: Fondo de Cultura Económica, 1996), 48I.

4. Desde un punto de vista empático, debe revisarse el estudio de Báez en Aby Warburg. El Atlas de imágenes Mnemosine: reproducción facsimilar, ed. Linda Báez Rubí (Ciudad de México: Universidad Nacional Autónoma de México, 20I2); Para una visión más escéptica, que se construye desde el conocimiento histórico y a la que el autor de este artículo es más cercano, véase Carlo Ginzburg, "De Aby Warburg a Ernst Gombrich. Notas sobre un problema de método", en Mitos, emblemas e indicios: morfología e historia (Barcelona: Gedisa, 1989), 38-74. 
En un principio, fueron parte de una reflexión literaria derivada de su actividad como ilustrador. Aunque aquí se usarán algunos ejemplos comerciales que probablemente no lo hayan comprometido demasiado, la calidad y cantidad de sus ilustraciones para Melville, y además para sus propios libros, hacen evidente que le concedió a la ilustración una jerarquía mayor en la producción de sentido durante la lectura. En este ejercicio de interpretación del texto, Covarrubias eligió algunos aspectos de los textos que ilustraba por encima de otros. Voy a usar la palabra "intervención" para describir su acción sobre una novela, pues no se entrelazaron sus dibujos con el texto ya concluido de Melville, que tiene sentido por sí mismo, pero sí pretendieron determinar la interpretación del texto. Al final de este artículo, sin embargo, intentaré demostrar que decidió modificar ese ejercicio fundamentalmente poético para que sus ilustraciones formaran parte de un debate científico del que ya se había convertido en un actor indispensable.

En 1935, The Limited Editions Club publicó Typee, una novela de Herman Melville, con ilustraciones de Covarrubias (fig. I). Esta novela narra las aventuras de un náufrago entre los caníbales de los mares del sur. Sobre el canibalismo hay un debate que rebasa los límites de este artículo. Se ha señalado que no eran los habitantes de las islas del Océano Pacífico los que se comían a los náufragos, o al menos no eran sólo ellos; a los marineros europeos y americanos también los devoraban, en caso de necesidad extrema, otros marineros europeos y americanos. De acuerdo con Caleb Crain, el canibalismo era uno de los fantasmas favoritos de la mentalidad colonial, que lo consideraba imposible de expresar en público. Había, en los Estados Unidos después de la Guerra Civil, muchos otros temas inefables: la homosexualidad y la mezcla racial, el mestizaje, eran asuntos que se callaban en público. La obra de Melville asocia la homosexualidad con el canibalismo, ambos excluidos del discurso público (aunque evocados estratégicamente por Melville para establecer el debate). ${ }^{5}$ Cito el pasaje de Typee donde el protagonista sospecha los rituales antropofágicos al pie de una figura de culto.

5. Caleb Crain, "Lovers of Human Flesh: Homosexuality and Cannibalism in Melville's Novels", American Literature 66, núm. I (1994): 35, https://doi.org/I0.2307/2927432. Sin embargo, se ha hecho notar que la homosexualidad como tal no era un tema vedado para Melville, que en un famoso capítulo de Moby Dick hizo que Ismael y Quequeg tomaran votos matrimoniales y después se acostaran "hugging his fellow male in that matrimonial style". Zach Hutchins, "Miscegenetic Melville: Race and Reconstruction in 'Clarel', Elh 80, núm. 4 (2013): II73-I203, https://www. jstor.org/stable/2447553I, argumenta que el propósito de Melville era promover el mestizaje, una idea que es consustancial a la ideología oficial mexicana, pero no en Estados Unidos. 
I. Miguel Covarrubias, Tiki in the Jungle, 1935, tinta aguada sobre papel, tomada de Herman Melville, Typee: A Romance of the South Seas, ed. John S. Fass (Nueva York: Limited Editions Club, 1935).

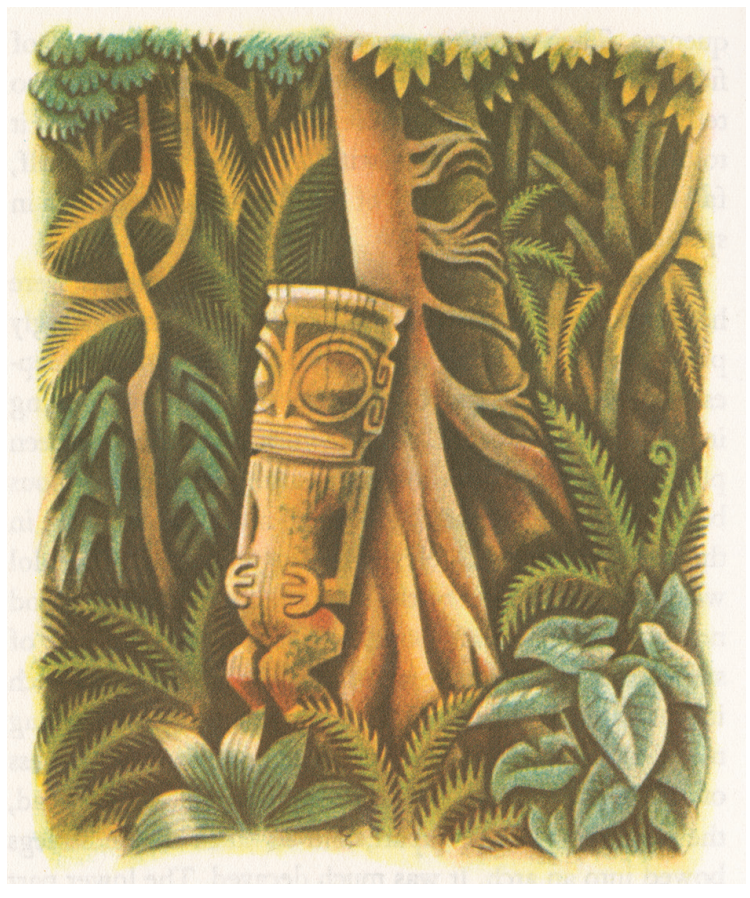

Nuestra jornada concluyó pronto, pues al escalar una altura inopinada, nos encontramos de manera abrupta con nuestro destino. Ojalá fuera posible bosquejar en palabras este punto tan vívidamente como lo recuerdo. Aquí estaban situados los surcos tabuados del valle - la escena de muchas fiestas prolongadas, de numerosos ritos horrendos. Tras las sombras de los árboles del pan consagrados reinaba un solemne crepúsculo - una sombra como de catedral. El espantoso genio de la devoción pagana parecía incubarse sobre el lugar, exhalando su palabra sobre todas las cosas. Aquí y allá, en las profundidades de estas terribles sombras, medio ocultas de la vista por masas de follaje colgante, se erigían los altares idolátricos de los salvajes, construidos de enormes bloques de piedra negra y pulida, puestos uno sobre el otro, sin cemento, hasta la altura de doce o quince pies, y coronados por un templo abierto rústico, cerrado por una hilera baja de carrizos, dentro de la que se podían ver, en varias etapas de descomposición, dádivas de fruto del árbol del pan y cacao, y las reliquias en putrefacción de algún sacrificio reciente. ${ }^{6}$

6. Herman Melville, Typee: a Peep at Polynesian Life (Evanston, Ill.: Northwestern University Press, 2003), 9I-92: "Our journey was soon at an end; for, scaling a sudden height, we came 
162

RENATO GONZÁLEZ MELLO

Nunca se dice exactamente qué es lo horrendo, qué es terrible o qué fue sacrificado. Crain examina la manera en que se articulan los protocolos de la literatura gótica en la sociedad estadounidense.

El descubrimiento del canibalismo en Melville se parece al descubrimiento de la homosexualidad en las novelas góticas. Una curiosidad irresistible anima al héroe. Éste es atraído por algo repulsivo y no controla sus acciones. ${ }^{7}$

Se trata de un pensamiento metafórico que califica a los habitantes de las islas con categorías que los ponen fuera de "la civilización" del siglo XIx. Esta distinción no es la misma que propone el racismo de raíces biológicas, que también se apoya en el cuerpo, pero un cuerpo cuidadosamente medido, esquematizado y clasificado. Eso podemos entenderlo, porque la historia del evolucionismo biológico rebasa los límites del siglo xIx. En cambio, la manera elíptica de referir los límites culturales de la civilización es difícil de descifrar. "El lector del siglo XIX leía con un sistema de connotaciones y presupuestos que hemos perdido". ${ }^{8}$ Más adelante veremos otro sistema de conversiones, intercambio y analogías que recuerdan la literatura decimonónica, aunque lo dicho hasta aquí no debería proyectarse en forma automática a las ilustraciones del dibujante mexicano del siglo xx, pues los dibujos de Covarrubias, ligeros y sin complicaciones, están en las antípodas del tono más bien tremendista de la novela.

La ilustración de Covarrubias no toma todo este terror, sino que lo domestica al señalar la cercanía de los dioses con la naturaleza. Tiki en la selva hace que la escultura en primer plano, que cubre su vientre con las manos, haga eco

abruptly upon the place of our destination. I wish that it were possible to sketch in words this spot as vividly as I recollect it. Here were situated the Taboo groves of the valley-the scene of many a prolonged feast, of many a horrid rite. Beneath the dark shadows of the consecreated bread-fruit trees there reigned a solemn twilight - a cathedral-like gloom. The frightful genius of pagan worship seemed to brood in silence over the place, breathing its spell upon every object around. Here and there, in the depths of these awful shades, half screened from sight by masses of overhanging foliage, rose the idolatrous altars of the savages, built of enormous blocks of black and polished stone, placed one upon another, without cement, to the height of twelve or fifteen feet, and surmounted by a rustic open temple, enclosed with a low picket of canes, within which might be seen, in various stages of decay, offerings of bread-fuit and cocoa-nuts, and the putrefying relics of some recent sacrifice."

7. Crain, "Lovers of Human Flesh", 32.

8. Crain, "Lovers of Human Flesh", 26. 
del árbol parásito a sus espaldas, que abraza el tronco. Como ocurre prácticamente sin excepción, las ilustraciones de Covarrubias, destinadas a un público estadounidense poco amigo de los misterios y el horror, son ligeras y luminosas, y uno tiene derecho a suponer que el pequeño dios selvático se agarra la barriga por una leve indigestión. Es posible que a pesar de esta estrategia de, podríamos decir, desintoxicación de la imagen, los lectores del texto imaginaran toda clase de horrores en el almuerzo del duende (pues la novela no hacía de esto un tema festivo). No obstante esa posible fantasmagoría, me imagino que la operación de Covarrubias fue fundamentalmente eficaz. En otro lugar he argumentado que, a diferencia de José Clemente Orozco, que en sus primeras incursiones en Estados Unidos prodigó la mordacidad y pesimismo de su temperamento, Covarrubias se adaptó bastante bien a un campo de las artes que no tenía mucho apetito para las escenas, figuras o insinuaciones de matanza, decadencia y malestar. ${ }^{9}$ Además de su conocimiento del arte y las sociedades del Pacífico (ya había publicado su famosa Island of Bali), esta trivialización de los tópicos más agresivos en la novela probablemente haya sido una de las causas de su elección como ilustrador.

Esta imagen del descubrimiento en la selva se volverá muy importante para la invención de los olmecas, y Covarrubias la repitió en ilustraciones muy dispares. La primera apareció en Life, en febrero de 1942, en un anuncio de diamantes. ${ }^{10} \mathrm{Al}$ pie de los árboles aparecían los pequeños diamantes, y sobre los propios árboles el autor grabó sus iniciales y las de Rose Roland, como si se tratara de un adolescente declarando su amor. La propia Rose publicó una foto muy semejante en Island of Bali, que apareció en 1937 (fig. 2). ${ }^{\text {II }}$ En un artículo sobre las cabezas de La Venta que publicó en I944 en la revista Dyn, de Wolfgang Paalen, Covarrubias publicó una fotografía de la selva tabasqueña, muy semejante a su ilustración para Melville

9. Renato González Mello, La máquina de pintar. Rivera, Orozco y la invención de un lenguaje (Ciudad de México: Universidad Nacional Autónoma de México-Instituto de Investigaciones Estéticas, 2008), I46.

Io. Véase Miguel Covarrubias, A half-lifetime, the old tree has guarded their names, 1942, acuarela y gouache sobre papel, en Miguel Covarrubias y De Beers Consolidated Mines, Ltd. 1942. "A half-lifetime, the old tree has guarded their names". Life, I6 de febrero de I942, 7I. La revista Life es accesible a través de Google Books: https://books.google.com.mx/books?id=QU4EAAAA MBAJ\&lpg=PA7I\&dq=\%22theold\%20tree\%2ohas\%2oguarded\%2otheir\%2onames\%22\&pg= PA7I\#v=onepage\&q=\%22the\%20oldtree\%2ohas\%2oguarded\%2otheir\%2onames\%22\&f=false

II. Miguel Covarrubias y Rosa Covarrubias, Island of Bali (Nueva York: Alfred A. Knopf, 1937), fotografía 8 . 


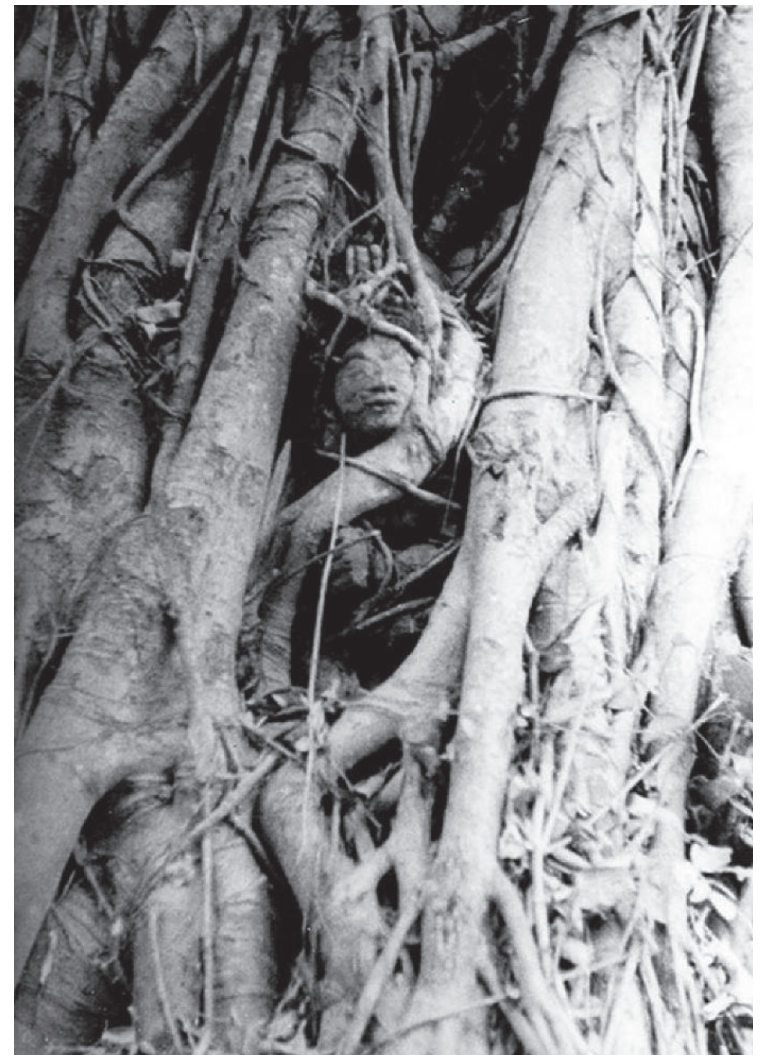

2. Rosa Covarrubias, A Statue Trapped in the Roots of a Waringin Tree, 1932-1933, plata sobre gelatina. Archivo Miguel Covarrubias. Sala de Archivos y Colecciones Especiales, Dirección de Bibliotecas, Universidad de las Américas, Puebla.

(fig. 3). ${ }^{12}$ El mismo motivo selvático reaparece en 1946 en una ilustración de Mexico South: ahí hay una cabeza monumental precedida por un jaguar, y en el fondo otro de esos árboles titánicos que tendrían una larga historia en su producción (fig. 4). ${ }^{13}$ De hecho, como veremos, el árbol era una figura de conocimiento crucial para sus teorías.

I2. Miguel Covarrubias, "La Venta. Colossal Heads and Jaguar Gods", Dyn, I944, 25; para un análisis integral de la relación de Dyn con la antropología, véase Daniel Garza Usabiaga, "Antropología como ciencia, antropología como política: las lecciones de Franz Boas en el Amerindian Number de Dyn de Wolfgang Paalen”, Anales del Instituto de Investigaciones Estéticas 33, núm. 98 (el 24 de mayo de 20II): I75-200, http://www.analesiie.unam.mx/index.php/analesiie/article/view/2365.

13. Miguel Covarrubia, Mexico South: The Isthmus of Tehuantepec (Nueva York: Alfred A. Knopf, 1946). 
3. Miguel Covarrubias,

Virgin Forest at La Venta,

Tabasco, ca. 1944, impreso.

Miguel Covarrubias, "La

Venta Colossal Heads and

Jaguar Gods", Dyn, núm.

6 (noviembre de 1944): 25,

tomado de Wolfgang Paalen's

Dyn: The Complete Reprint, ed. Christian Kloyber (VienaNueva York: Springer, 2000).

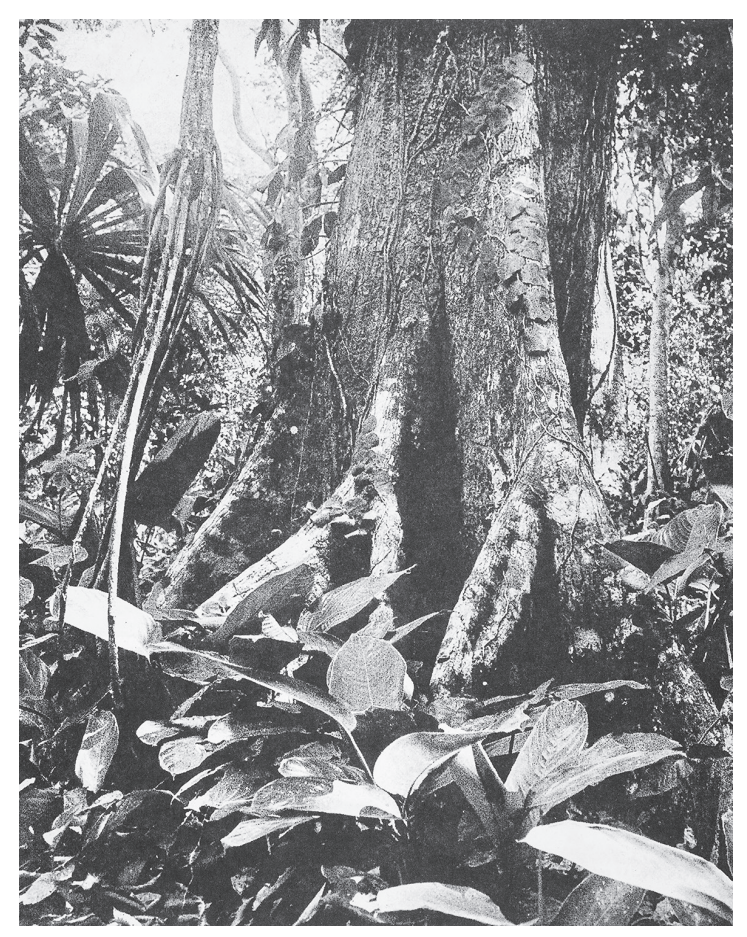

Aunque podemos evocar a propósito de este asunto el ejemplo de Paul Gauguin, sería uno entre muchos elementos que nos recuerdan el simbolismo: la reflexión sobre las relaciones entre el deseo y la fe, la construcción de espacios selváticos llenos de magia, la inquietud por una posible regresión hacia lo primitivo. ${ }^{14}$ Notemos que todo está muy dulcificado. Poco después, cuando José Clemente Orozco aborda tópicos semejantes, pondrá en ello toda la furia de las paranoias decimonónicas. Lo hizo en el Hospicio Cabañas, en Guadalajara; porque el propio Orozco había constatado que el público de los Estados Unidos no se enfrentaba de buena gana a la imagen de sus propios prejuicios raciales. En esto se distinguía del público mexicano de intelectuales, que recibía de buen grado la dramatización de su propio sistema ideológico. Al evolucionar el pensamiento de Covarrubias, incurrió en tópicos que hicieron indispensable

I4. Pienso de manera muy general en lo que argumenta Bram Dijkstra, Ídolos de perversidad: la imagen de la mujer en la cultura de fin de siglo (Madrid: Debate, 1994). 


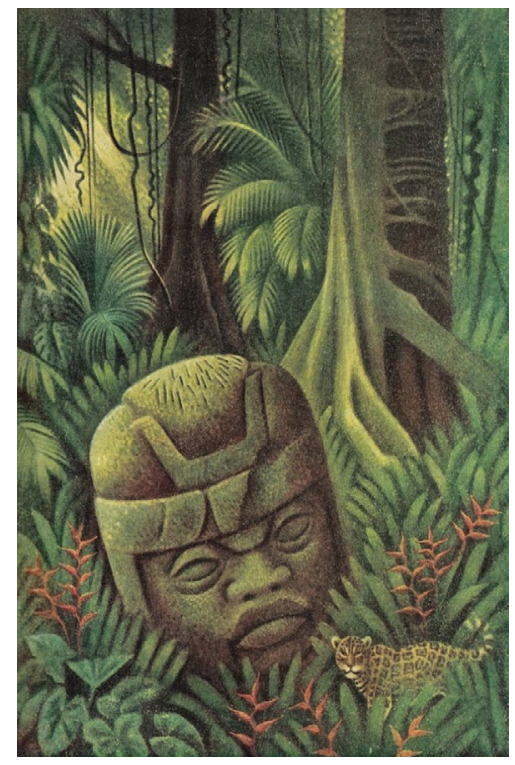

4. Miguel Covarrubias, "The colossal head in the Jungle at La Venta”, ca. 1946, impreso, tomada de Mexico South. The Ishtmus of Tehuantepec (Nueva York: Alfred A. Knopf, 1946).

una forma muy sotifisticada para matizar un pensamiento sobre la "raza" que fue cambiando su lugar a lo largo de la década de los años cuarenta.

\section{Stevenson en Iguala ${ }^{\text {I5 }}$}

Typee no fue, sin embargo, el único modelo literario para sus devaneos antropológicos, aunque me temo que seguiremos adentrándonos en tópicos francamente colonialistas. Citemos brevemente su artículo seminal sobre los olmecas para entender cómo comenzó su obsesión por aquellos antiguos habitantes de las selvas:

En el estado de Guerrero, allá en las épocas anteriores a las carreteras y el turismo, en una pulquería de Iguala, donde los campesinos de la región cambiaban sus ídolos por mezcal, adquirí algunos objetos arqueológicos muy extrańos: idolitos de personajes

I5. Los tres apartados que siguen llegan por una vía distinta a conclusiones semejantes a las de Khristaan D. Villela, "Miguel Covarrubias and Twenty Centuries of Latin American Art, from the Olmec to the Inka”, en Miguel Covarrubias: Drawing a Cosmopolitan Line; Georgia O'Keeffe Museum, de Carolyn Kastner (Austin: University of Texas Press/Georgia O’Keeffe Museum, 20I4), 49-75, cuya lectura me permitió precisar muchas de las ideas aquí contenidas. 
5. "Estatuilla de serpentina negra. Distrito de Iguala, Guerrero (Col. M. Covarrubias)”, y "Estatuilla de basalto representando un sordo

(?). Veracruz (Col. M. Covarrubias)", $c a$. 1946, impreso. Archivo Miguel Covarrubias.

Sala de Archivos y Colecciones Especiales,

Dirección de Bibliotecas, Universidad de las Américas, Puebla.

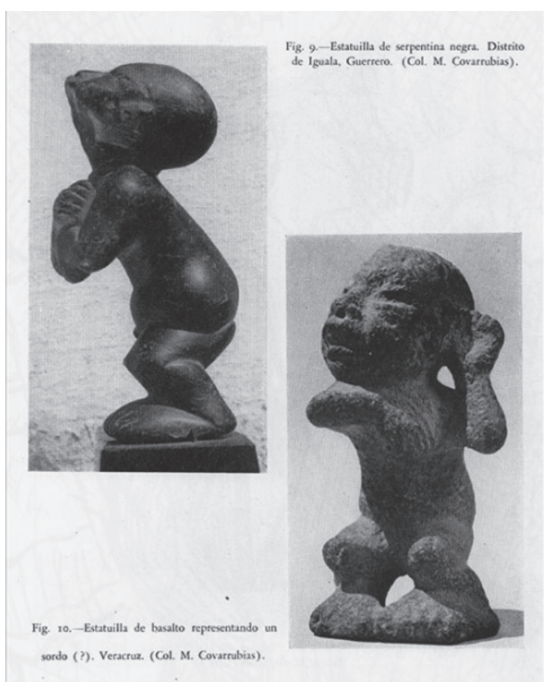

gordos, de rasgos extraordinariamente mongoloides y con gruesas bocas displicentes. Había entre ellos un cuerpecito rechoncho y sin cabeza, tallado en serpentina negra pulida con un realismo y maestría asombrosos. [...] Ocho años después el pintor Diego Rivera, otro fanático coleccionista, me obsequió una cabecita de serpentina negra que milagrosamente resultó ser la cabeza que le faltaba al cuerpecito de Iguala. Era redondeada en forma de aguacate, con los ojos abotagados, los carrillos inflados y con una extrañísima boca, la boca de un monstruo, de un niño o enano nacido sin la mandíbula inferior, mostrando la tráquea tallada en forma realista. ${ }^{\mathrm{I}} 6$

Una historia que recuerda El diablo en la botella, de Robert Louis Stevenson. ${ }^{17}$ Covarrubias publicó la figurilla en Mexico South, en 1954 (fig. 5). ${ }^{18}$ Obsesionado con los objetos que le llegaban de esta manera poco usual, Covarrubias llegó a desarrollar una teoría completa sobre los rasgos estilísticos que tenían en común. Esto lo llevó a participar en la Mesa Redonda de la Sociedad Mexicana

I6. Miguel Covarrubias, "El arte 'olmeca' o de La Venta”, Cuadernos Americanos XXVIII, núm. 4 (I946): I53.

17. Carlo Ginzburg, Ninguna isla es una isla: cuatro visiones de la literatura inglesa desde una perspectiva mundial (Villahermosa,Tabasco: Universidad Juárez Autónoma de Tabasco, 2003), 79-97.

I8. Covarrubias, Mexico South, 8I, ilustración I2 B. 
de Antropología de $1942,{ }^{19}$ dedicada a los mayas y olmecas, conjuntamente con Alfonso Caso, para leer una breve ponencia sobre el estilo que en adelante se llamaría "olmeca". ${ }^{20}$

En una investigación muy profunda, Haydée López Hernández reconstruye en los trabajos de Covarrubias con Caso la invención de una "cultura madre" para Mesoamérica, ${ }^{2 \mathrm{~T}}$ pero este artefacto retórico no quedó libre de muchas dudas, tal vez por las circunstancias dramáticas de su aparición. En 1968, haciendo un recuento de la aparición de "los olmecas", Matthew Stirling recordó que la similitud estilística entre distintos objetos que provenían de la Costa del Golfo y de la antigüedad remota se había señalado desde tiempo antes. ${ }^{22} \mathrm{~A}$ partir de 1939, las exploraciones del propio Stirling en Tres Zapotes, La Venta y Cerro de las Mesas dispararon un alud de trabajos académicos sobre los pueblos que pudieran haber hecho las cabezas colosales del Golfo. ${ }^{23}$

Pero los acontecimientos de la arqueología no eran los únicos que tenían visibilidad pública en abril de 1942. En septiembre de 194I había comenzado el larguísimo sitio de Leningrado. En diciembre, el Ejército Rojo había logrado impedir la entrada de los alemanes a Moscú. El régimen nazi distribuía propaganda que aseguraba su pronta victoria. En el Pacífico todo había ocurrido con rapidez: los japoneses habían atacado Pearl Harbor a finales de I94I, y para abril habían echado a MacArthur de las Filipinas. Faltaba más de un mes para la batalla de Midway, que cambió un poco el curso de la guerra. Es probable que los asistentes al congreso de Tuxtla Gutiérrez estuvieran enterados del bombardeo de Tokio. No estaba muy claro quién iba a ganar la guerra. Grandes ejércitos se desplazaban de un continente a otro. Escuadrones volaban a través de distancias que hubieran parecido de fantasía pocos ańos antes. El mundo se

19. Sociedad Mexicana de Antropología (sMA), Mayas y olmecas; segunda reunión de mesa redonda sobre problemas antropológicos de México y Centro América (Ciudad de México: Talleres de la Editorial Stylo, 1942).

20. SMA, Mayas y olmecas, 43-49. En aquel momento Wigberto Jiménez Moreno sugirió no hablar de los escultores preclásicos de las cabezas colosales como "olmecas", para no confundirlos con los olmecas históricos mencionados en las fuentes escritas. Sin embargo, el gentilicio se quedó.

21. Haydée López Hernández, En busca del alma nacional. La arqueologia y la construcción del origen de la historia nacional en México (I867-1942) (México: Instituto Nacional de Antropología e Historia, 20I8), 26I-322, hace un relato muy emocionante del proceso que llevó a la Mesa Redonda. 22. Matthew W. Stirling, "Early History of the Olmec Problem", en Dumbarton Oaks Conference on the Olmec — Dumbarton Oaks (Washington, D. c.: Dumbarton Oaks, I968), I-8, https:// www.doaks.org/resources/publications/books/dumbarton-oaks-conference-on-the-olmec, 2.

23. Stirling, "Early History of the Olmec Problem", 3. 
parecía a las novelas de H.G. Wells, en especial a The War in the Air. Había un poco de ansiedad sobre las lealtades del gobierno mexicano. Entre los asistentes a la Mesa Redonda había un enviado de la Embajada de Estados Unidos. Estaba, también, John McAndrew; "arquitecto", como dice la memoria, pero en ese momento con un empleo en el Departamento de Estado, en la Oficina para Asuntos Interamericanos de Nelson Rockefeller. ${ }^{24}$ Entre los asistentes había también varios académicos que estaban en el exilio por el ascenso de distintas dictaduras en Europa y América: Pedro Bosch Gimpera, Paul Kirchhoff, Juan Comas y Jorge A. Vivó. Julio de la Fuente, que había sido colaborador de Ruta, quizás la primera revista estalinista de México. Seguramente un examen más cuidadoso en esta ensalada multinacional, pero en la que predominaban mexicanos y norteamericanos, dejaría ver más lazos políticos. ${ }^{25}$ Alfonso Caso, que presentó su participación conjunta con Covarrubias, de ninguna manera podría ser imaginado como un personaje ajeno o indiferente a la política. Quizás el periódico se tardaba en llegar a Tuxtla Gutiérrez (los congresistas habían hecho un viaje en tren de varios días); buscó en vano historias de la radio en Chiapas. Es posible que, para conocer noticias internacionales que difícilmente habrán considerado ajenas, los congresistas tuvieran que buscar un radio de onda corta. Los trece americanos presentes entre los "invitados especiales" habrían tenido un interés especial, pues ellos mismos o sus familias podían ser reclutados.

Covarrubias conocía personalmente los lugares donde se habían librado algunas de las batallas más importantes. La isla de Bali había caído en manos japonesas en febrero y le siguió Java, en marzo de 1942. La isla de Bali conquistada. La isla de Bali colonizada. Pero justo porque conocía los lugares y a los actores de primera mano, en sitios que distaban entre sí por millares de kilómetros, millas o leguas, Covarrubias menos que nadie puede ser considerado

24. Madges Bacon, John McAndrew's, Modernist Vision: From the Vassar College Art Library to the Museum of Modern Art in New York (Nueva York: Princeton Architectural Press, 2018): 165-169. Sobre los lazos de McAndrew en México, véase Keith L. Eggener, "Nationalism, Internationalism and the 'Naturalisation' of Modern Architecture in the United States, 1925-1940," National Identities 8, no. 3 (September I, 2006): 243-258, https://doi.org/Io.Io80/I4608940600842540. Sobre los hechos de la guerra, véase Gerhard L. Winberg, A. World at Arms. A Global History of World War II (New York: Cambridge University Press, 1994).

25. Sobre Julio de la Fuente véase Claudia Garay Molina, "De Estridentópolis a la ciudad roja. La ruta hacia una literatura y gráfica proletaria”, en Renato González Mello y Anthony Stanton, eds., Vanguardia en México I9I5-I940 (México: INBA-Museo Nacional de Arte, 2013), I72-I83. La lista en SMA, Mayas y olmecas, I7-I8. 
inocente sobre lo que estaba ocurriendo. Sí: la Armada Imperial de Japón había tomado distintos puntos de Asia e Indonesia. Pero eran sitios que habían sido colonizados previamente por las potencias europeas, y por los Estados Unidos. Cuando Covarrubias los visitó, venía de Nueva York, y era uno de los pocos inmigrantes de América Latina a quien se reconocía en aquella metrópoli como un igual. ¿Cuál era la diferencia si ahora era un país asiático, y no europeo, el que atacaba a otros países asiáticos?

Para quienes se dedican a la antropología de Mesoamérica, la Segunda Mesa Redonda es casi tan importante como lo fue la batalla de Stalingrado en la Segunda Guerra Mundial. En 1942 todavía no se hablaba de "Mesoamérica”. Tampoco se sabía que el Ejército Rojo iba a ganar la batalla de Stalingrado. El buque Potrero del Llano iba a ser hundido una semana después de que concluyeran los trabajos de los especialistas. ${ }^{26}$ En la Segunda Mesa Redonda se definió un concepto bastante elusivo para la historia de la antigüedad mexicana, pero también muy importante. Los participantes, esa mezcla de políticos y antropólogos, vieron como un ex jurista arqueólogo y un caricaturista plantearon una noción que intentaba resolver una serie de contradicciones en la interpretación de las excavaciones arqueológicas: "el estilo olmeca". Hacer de este pequeño episodio un capítulo de "historia de las ideas" puede parecer abusivo. En una bibliografía comentada que se publicó en 1966, Luis Villoro hacía la siguiente reflexión: "El término 'historia de las ideas' no deja de ser equívoco. En un sentido amplio debería aplicarse a toda la historia cultural; pero el uso le ha dado un sentido más restringido: suele referirse exclusivamente a la historia de las ideas y creencias generales en que se manifiesta una concepción del mundo y de la vida”. ${ }^{27}$

Los asistentes a la Mesa Redonda tenían ante ellos una visión del mundo. Una bastante lúgubre. En este viaje a al centro de sus obsesiones, quizás hayan querido olvidar el fin del mundo del que hablaban los periódicos, para imaginar los orígenes de otro mundo, muy antiguo, seguramente mejor, aunque también conflictivo. Las preguntas que se plantearon en esa reunión fueron estrictamente académicas, pero es dudoso que el público o los participantes hubieran pensado en el pasado en términos puramente abstractos. Fue ahí, en todo caso, donde Covarrubias presentó con Alfonso Caso su ponencia

26. Enrique Plasencia de la Parra, "Las infanterías invisibles: mexicanos en la segunda guerra mundial”, Historia Mexicana, núm. 207 (2003): 1027.

27. Luis Villoro, "Historia de las ideas.", Historia Mexicana I5, núms. 58-59 (octubre de 1965): 167. 
sobre los olmecas, postulando la existencia de una cultura madre u originaria para las civilizaciones que, apenas un año después, terminarían llamándose "mesoamericanas". ${ }^{28}$

La intervención de Caso y Covarrubias tenía una ambigüedad que hoy resulta un poco inquietante, tal vez porque sólo contamos con las síntesis. El problema de la Mesa Redonda se había definido en el anterior debate, que había culminado en la Mesa Redonda de 194I, sobre la identidad de los pueblos que las fuentes escritas llamaban "olmecas". Pero en Tres Zapotes se había encontrado una estela con una fecha que situaba los vestigios del Golfo en la tercera centuria antes de Cristo. ${ }^{29}$ Era evidente que los "olmecas" a los que mencionaba Sahagún, y que un año antes habían sido situados en el Epiclásico, no podían ser los mismos. Había más de mil años de diferencia. ¿Quiénes eran entonces los talladores de las grandes cabezas, los constructores de los montículos? En el análisis de Haydée López, una parte significativa del debate se refirió de manera un tanto confusa a la disparidad entre lo que decían las fuentes, las conclusiones de Wigberto Jiménez Moreno un año antes (y que habrían de perdurar mucho más), y unos hallazgos arqueológicos que algunos participantes probablemente conocieron en el propio evento. ${ }^{30}$

Caso y Covarrubias habían visitado las excavaciones de Stirling, Covarrubias en dos ocasiones. ${ }^{3 \mathrm{I}}$ En su ponencia, se refirieron a figuras y figurillas encontradas en sitios que iban de Michoacán hasta Costa Rica. Al describir los hallazgos, mezclaron la caracterización de los objetos con la descripción de las personas: "Dos tipos físicos parecen estar representados en los objetos 'olmecas'. Uno de nariz chata y labios muy gruesos, y otro de nariz fina y labios más delgados. Sin embargo, estos dos tipos tiene características comunes que autorizan para colocar los objetos que los representan dentro de una sola cultura". ${ }^{32}$

Los dos estudiosos parecían convencidos de que las representaciones correspondían con la realidad de la antropología física, lo que fue objeto de discusión y no pocas críticas por Juan Comas, Daniel Rubín de la Borbolla,

28. SMA, Mayas y olmecas.

29. López Hernández, En busca del alma nacional, 273-279. Podía variar un poco, dependiendo de cómo se interpretara.

30. López Hernández, En busca del alma nacional, 299-305.

31. López Hernández, En busca del alma nacional, 288, 314.

32. SMA, Mayas y olmecas, 42. 
Hanna Kirchhoff, Manuel Maldonado y Eusebio Dávalos. ${ }^{33}$ Esto marcaba una de las preguntas más complicadas en este debate: ¿el "estilo" uniforme de aquellos hallazgos permitiría postular la existencia de un "pueblo", una "sociedad" o una "cultura" igualmente uniforme? Vienen a la memoria las numerosas fotografías de esta época, donde campesinos que posiblemente ayudaron en distintas excavaciones posan junto a los hallazgos; imágenes que intentan establecer una tipología uniforme entre la producción artística y los rasgos somáticos. ${ }^{34}$ El problema en la participación de Caso y Covarrubias, que se discute hasta la fecha, era que la invención del "estilo" olmeca llevaba, de manera implícita, a la invención del grupo humano, la cultura, "el pueblo" que había articulado aquel sistema antiguo de convenciones, aquel "estilo" (fig. 6).

Aunque esta ambigüedad era importante, Covarrubias y Caso postularon la autonomía de las figuras, particularmente del motivo del "tigre". No se podría exagerar la importancia de este párrafo, donde usan una noción que era, en los años cuarenta, central para la historia del arte: la noción de "estilo".

El tigre es el motivo básico del arte "olmeca", tal vez el animal totémico de los pueblos que originaron este estilo. Es un arte impregnado de tigres, elementos de tigre y otras ideas derivadas del tigre. Así, tenemos verdaderos tigres con grandes colmillos, o bien tigres antropomorfos en actitudes medio humanas, medio felinas, con adornos y vestimenta de hombres. 35

Hay pues tres órdenes de ambivalencia. Por una parte, proponían que los olmecas habían sido "[...] seres gordos y chaparros, con las quijadas anchas, chatos, de labios gruesos, ojos mongoloides [...]"; en segundo lugar, aseguraban que sus objetos eran "casi siempre $[\ldots]$ lisos, sin decoración $[\ldots]$ de un estilo sencillo y sobrio, casi geométrico, de cuervas suaves y rectángulos esgrafiados". Finalmente, y de manera un tanto contradictoria, aseguraban que las características somáticas de los personajes eran, en realidad, una preferencia estilística: "Este estilo de dibujos esgrafiados"; "no solamente en su significado

33. López Hernández, En busca del alma nacional, 69-72.

34. Deborah Dorotinsky, "Para medir el cuerpo de la nación: Antropología física y visualidad racialista en el marco de recepción de la biotipología en México", en Una historia de la eugenesia. Argentina y las redes biopoliticas internacionales. I9I2-I945, ed. Marisa Miranda y Gustavo Vallejo (Buenos Aires: Biblos, 20I2), 506, https://www.academia.edu/7857992/.

35. SMA, Mayas y olmecas, "Para medir el cuerpo de la nación", 47. Las cursivas son mías. 
6. Rosa Covarrubias (18951970), Hombre con una cabeza de piedra en la mano, plata sobre gelatina. Archivo Miguel Covarrubias. Sala de Archivos y Colecciones Especiales, Dirección de Bibliotecas, Universidad de las Américas, Puebla.

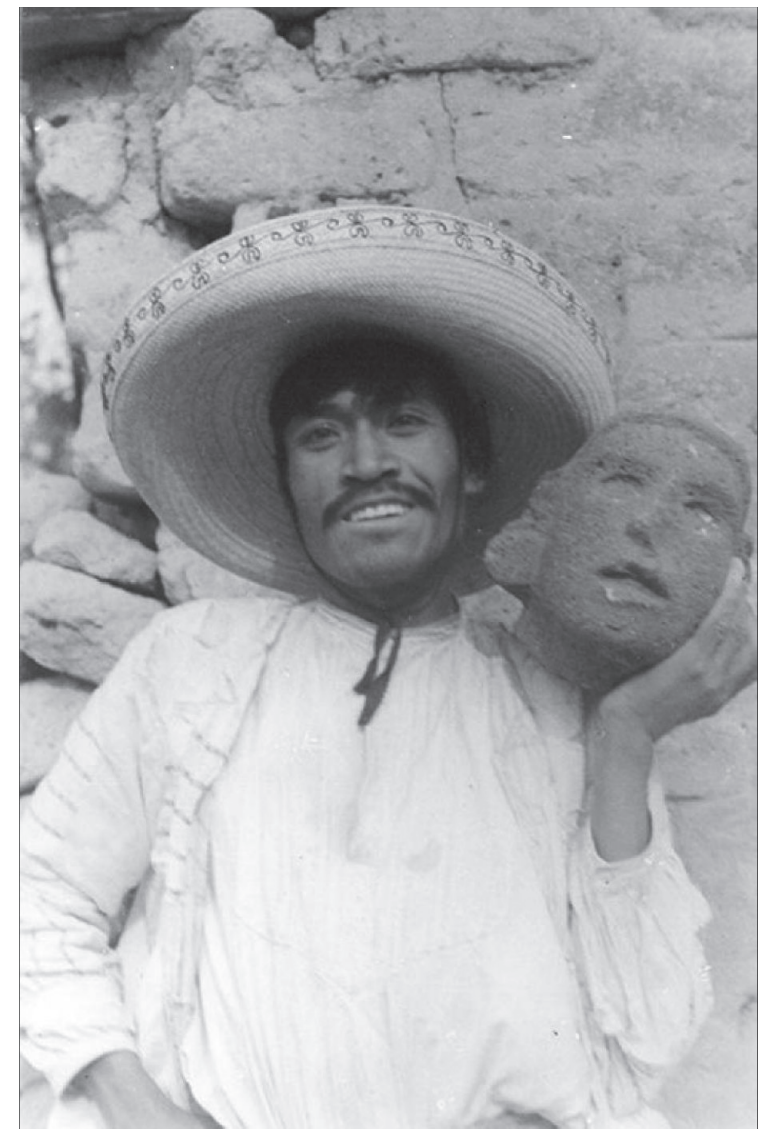

religioso, sino también en su evolución estilística". Finalmente, sintetizaban todos estos rasgos en la figura del felino (en realidad, el jaguar). ${ }^{6}$

Hay que entender que en este momento la idea no está completamente desarrollada y el dibujo que la representa tampoco (fig. 7). Pero ya para terminar, Alfonso Caso procuró hacer un resumen de los puntos de vista que se habían expresado en aquella conferencia.

El estilo que los arqueólogos llamamos "olmeca", ¿a cuál de los olmecas históricos corresponde?

36. SMA, Mayas y olmecas, "Para medir el cuerpo de la nación", 46-47. 
DOI: https://doi.org/10.22201/iie.18703062e.2020.Suplemento.2708

I74

RENATO GONZÁLEZ MELLO
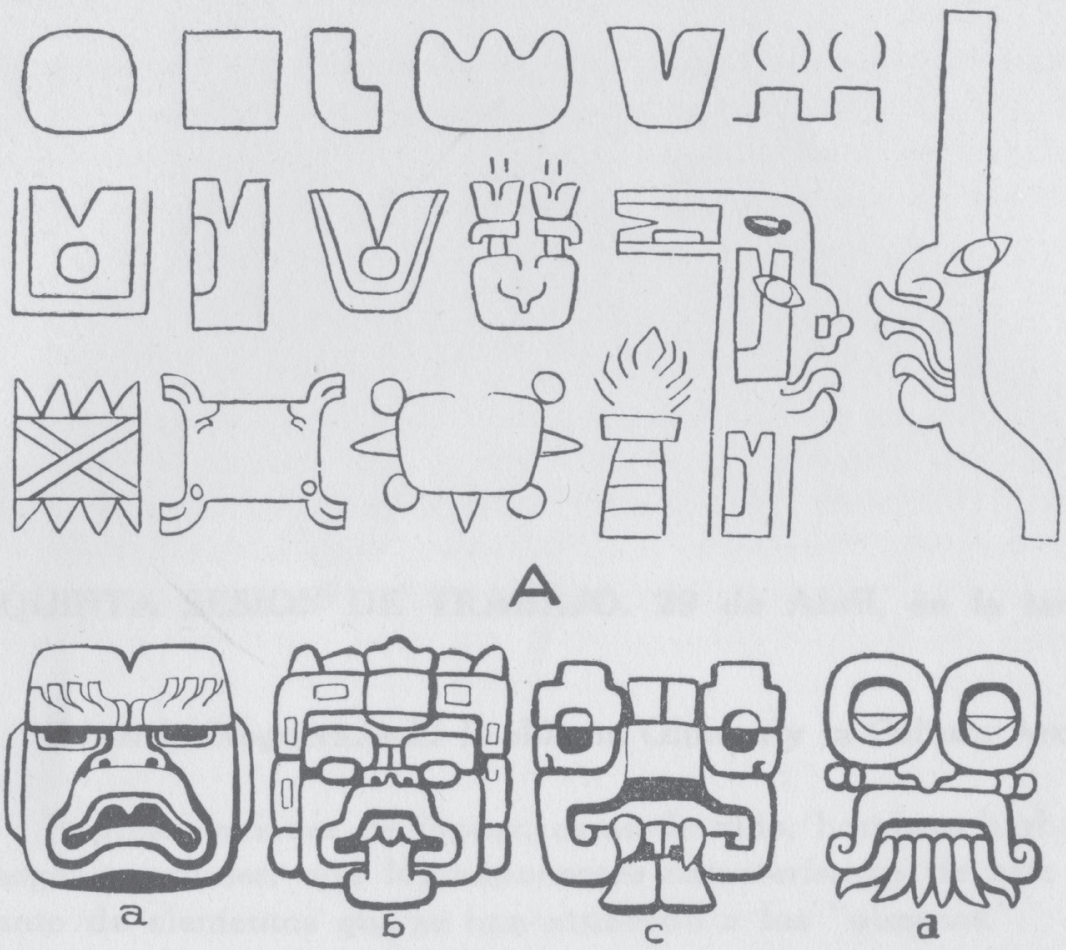

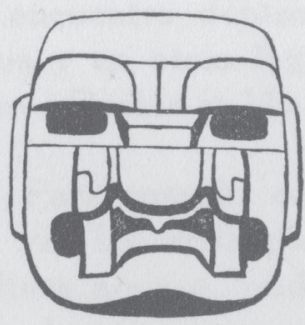

e

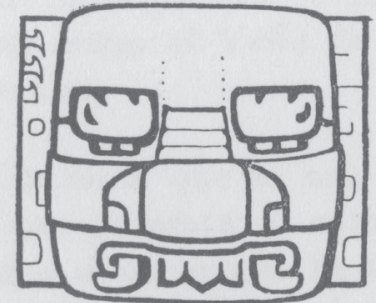

$f$

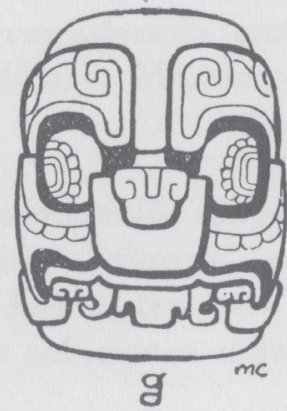

7. Miguel Covarrubias, "A. Algunos glifos y motivos esgrafiados típicos del arte 'olmeca'. / B. El motivo básico 'máscara de tigre' y dioses de la lluvia”, 1942, impreso, tomado de Mayas y olmecas. Segunda Reunión de Mesa Redonda sobre problemas antropológicos de México y Centro América. Sociedad Mexicana de Antropología (México: Talleres de la Editorial Stylo, 1942), 49. 
$[\ldots]$

La cultura "olmeca" no es en ningún sentido primitiva. Más bien debe llamársele una cultura clásica, de gran finura, que implica siglos de preparación o formación y que influye esencialmente en las culturas posteriores. ${ }^{37}$

Al decir "cultura clásica", los dos autores invocaban la noción de "estilo": lo olmeca no era "un estilo local"; "este estilo no posee rasgos o elementos de otras culturas". Da la impresión de que "estilo" y "cultura" se empleaban como nociones que podían intercambiarse. Esta noción de "estilo" es distinta de la categoría clasificatoria de los formalismos del siglo xx. Caso se refiere al "estilo" en su noción más antigua: como calidad. Cuando dice "una cultura clásica", se refiere a una construcción ideológica absoluta (para el clasicismo histórico, sólo podía haber "una" cultura clásica, pero no una entre otras). "Una cultura clásica, de gran finura". El fundamento de esta afirmación tal vez no era tan consistente como hubieran querido Caso y Covarrubias. La ilustración muestra dos cosas: un catálogo breve de motivos esgrafiados, todos de origen olmeca; y un inventario también pequeño de máscaras de distintos orígenes. La suposición, no del todo desarrollada, es que los motivos esgrafiados darían lugar a una serie de costumbres iconográficas que cristalizarían en las máscaras; pero no estaban claras las relaciones entre unos dibujos y otros.

Pienso que éste fue un problema para Covarrubias porque luego elaboró un diagrama nuevo y mucho más ambicioso, pero antes hay que hacer una pausa. Es muy posible que las discusiones en la mesa redonda, que no fueron triviales, lo hayan llevado a examinar sus propias ideas, y a reformular un poco una reflexión que se apoyaba, aunque de manera insuficiente, en una serie de tradiciones literarias y de representación visual. Los debates en Tuxtla Gutiérrez muy posiblemente lo empujaron a sistematizar lo que pensaba sobre aquellas culturas muy antiguas y su "estilo", adoptando las herramientas de una disciplina nueva con una naturalidad y sensibilidad que nunca ha dejado de sorprender a propios y a extrańos. En este sentido, recurrió a una figura (la del árbol) que lo había ocupado previamente, pero para resignificarla de manera radical. 
DOI: https://doi.org/10.22201/iie.18703062e.2020.Suplemento.2708

176

RENATO GONZÁLEZ MELLO

\section{Los hallazgos en Tlatilco}

En noviembre de 1942, Covarrubias inició junto con Hugo Moedano Koer un proyecto de excavación en Tlatilco que abarcaría varias temporadas y que además modificó seriamente su percepción de la historia de los olmecas. La excavación arqueológica lo orilló a adoptar explicaciones más afines a la historia social, aunque la forma que eligió para exponer esas teorías omita en general los factores sociales. La documentación de este proyecto es sumamente interesante. Por una parte, Covarrubias redacta explicaciones y dibuja los objetos y esqueletos que van encontrándose. Hay también abundante documentación fotográfica. Se acepta, y la documentación del archivo parece confirmarlo, que Covarrubias hizo las gestiones para financiar este proyecto de investigación, en tanto que Moedano llevó a cabo el proceso técnico y científico necesario para validar académicamente el trabajo arqueológico. La labor de Moedano no podría considerarse, sin embargo, subordinada o tangencial. Sostengo que en el diálogo con el artista, muy visible en la documentación del proyecto, su aportación fue bastante significativa.

Las ideas que surgieron de esta prolongada investigación probablemente hayan sido demasiado ambiciosas, y es posible que los medios visuales hayan sido necesarios para sintetizar hipótesis y exponer contradicciones que no podían resolverse con facilidad. Covarrubias y Moedano se convencieron de que la historia antigua de México había sido una confrontación entre grupos muy pobres que se defendían con éxito variable de sofisticadas aristocracias suntuarias. Tal vez el conocido difusionismo de Covarrubias, en lo que toca a la posible influencia transpacífica, haya quedado como una hipótesis imposible de demostrar. En cambio, la idea de que el México antiguo fue un territorio de emigraciones, invasiones y conquistas es aún vigente.

Recordando la vida y obra de su amigo para la Oxford Encyclopedia of Mesoamerican Studies, Michael Coe dijo que Covarrubias pensaba en los habitantes del sitio de Tlatilco, en el norte de la Ciudad de México, como una sociedad democrática de campesinos, gente simple y sin jerarquía que había sido conquistada por los olmecas. Y estos últimos, los olmecas, le habían impuesto un "estilo" a esa sociedad originalmente equitativa..$^{38}$ En este punto de vista, el "estilo" era una herramienta de poder, de política imperial y el medio para

38. Michael D. Coe, "Covarrubias, Miguel”, en The Oxford Encyclopedia of Mesoamerican Cultures v. I, David Carrasco (Nueva York: Oxford University Press, 200I), 277-278. 
la reunión de una élite. Emigrante él mismo, participante en muchas operaciones de negociación y supresión de culturas, es probable que al pensar en aquellas sociedades y personas del pasado remoto las subsumiera en la historia de sus amigos y conocidos: Alfred Barr, director del Museo de Arte Moderno de Nueva York; Diego Rivera; Frank Crowninshield, editor de Vanity Fair; o Nelson Rockefeller, que en los ańos cuarenta organizaba una alianza continental para la guerra desde la oficina del coordinador de Asuntos Interamericanos del Departamento de Estado, pero además era el patrono más importante del момA.

También encontramos eco de esta idea en los escritos de Hugo Moedano, que en un artículo posiblemente escrito al final de los años cuarenta se imagina a los toltecas como un pueblo sumamente culto, viviendo en Tenochtitlán bajo el yugo de los mexicas. ${ }^{39}$ Ahora bien: no hacía falta irse al pasado remoto para pensar en un proceso de sojuzgamiento intelectual de esta naturaleza. La élite intelectual de México, compuesta en una medida considerable por los hijos de la antigua élite porfiriana, tenía una relación muy ambivalente con los revolucionarios venidos del norte y que habían instaurado el régimen de partido único que sobrevivió hasta el final del siglo. Poniéndonos weberianos, podríamos pensar en una conciencia meritocrática, como la de la burocracia china, que se expresa en esta fantasía de una sociedad de sabios — o de campesinos- que sobrevive bajo los guerreros.

A medida que progresaron sus excavaciones en Tlatilco, primero con Moedano y luego con Daniel Rubín de la Borbolla, Covarrubias se convenció de que había encontrado una cultura campesina que había sido sepultada bajo una capa de clasicismo: aristocrático, perfecto y tal vez tan autoritario como el modernismo de sus amigos americanos.

Los tlatilcas hicieron figurillas de barro encantadoras y expresivas, modeladas en forma directa y con un sentimiento por la forma que se perdió después, cuando las artes se volvieron más formales y sujetas a las imitaciones de un simbolismo esotérico y carente de emociones. Su mentalidad artística era radicalmente distinta de la que tuvieron los creadores de las culturas clásicas más tardías. ${ }^{40}$

39. Hugo Moedano Koer, "Ce acatl igual ome acatl, como fin de xiuhmolpilli", Revista Mexicana de Estudios Antropológicos I2 (195I): I03-3I.

40. Miguel Covarrubias, "Tlatilco. Archaic Mexican Art and Culture”, Dyn (1943): 45. 


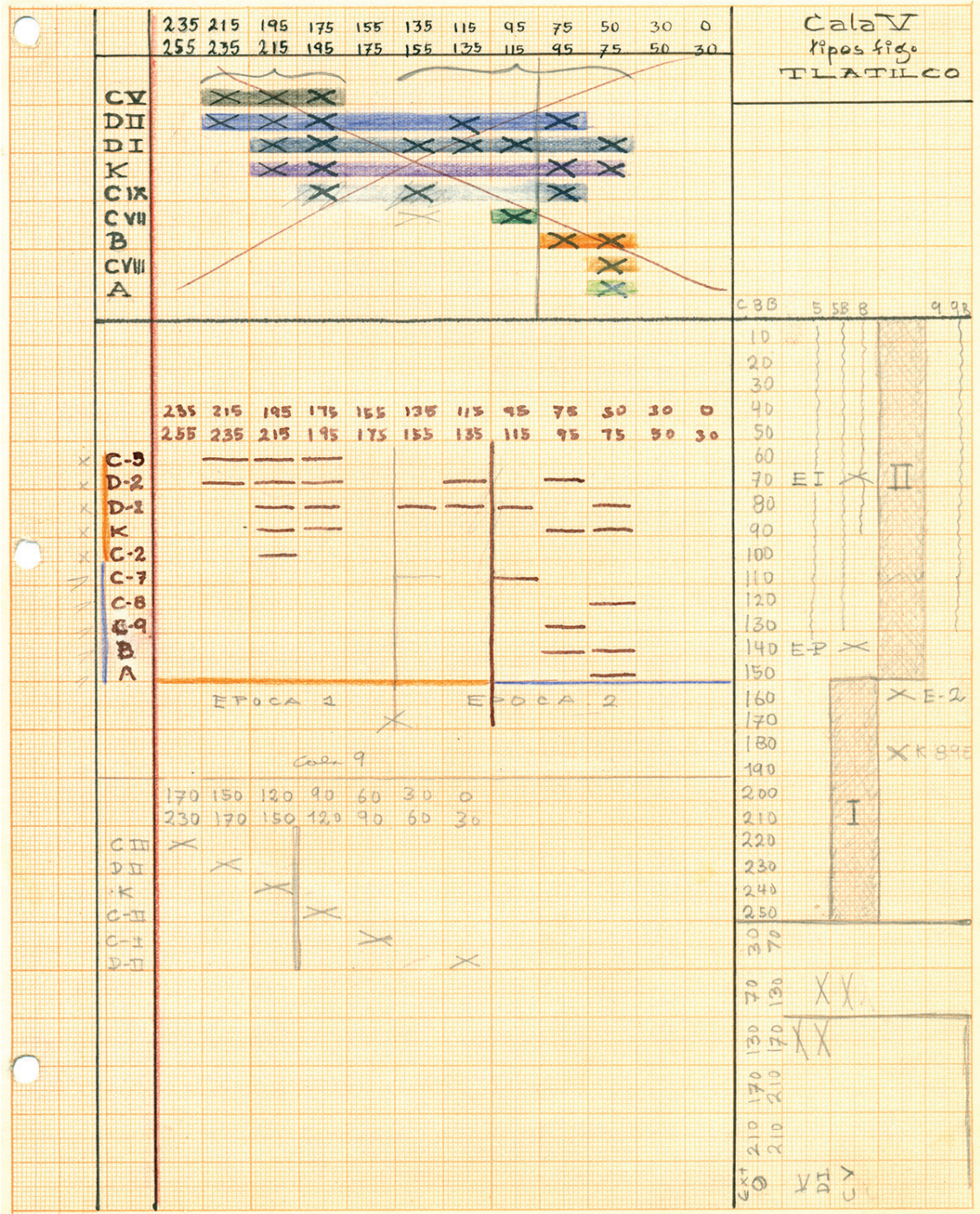

8. Miguel Covarrubias, Tlatilco. Cala V, 1942-1949 (posiblemente 1943), tinta y lápiz sobre papel. Archivo Miguel Covarrubias. Sala de Archivos y Colecciones Especiales, Dirección de Bibliotecas, Universidad de las Américas, Puebla. 


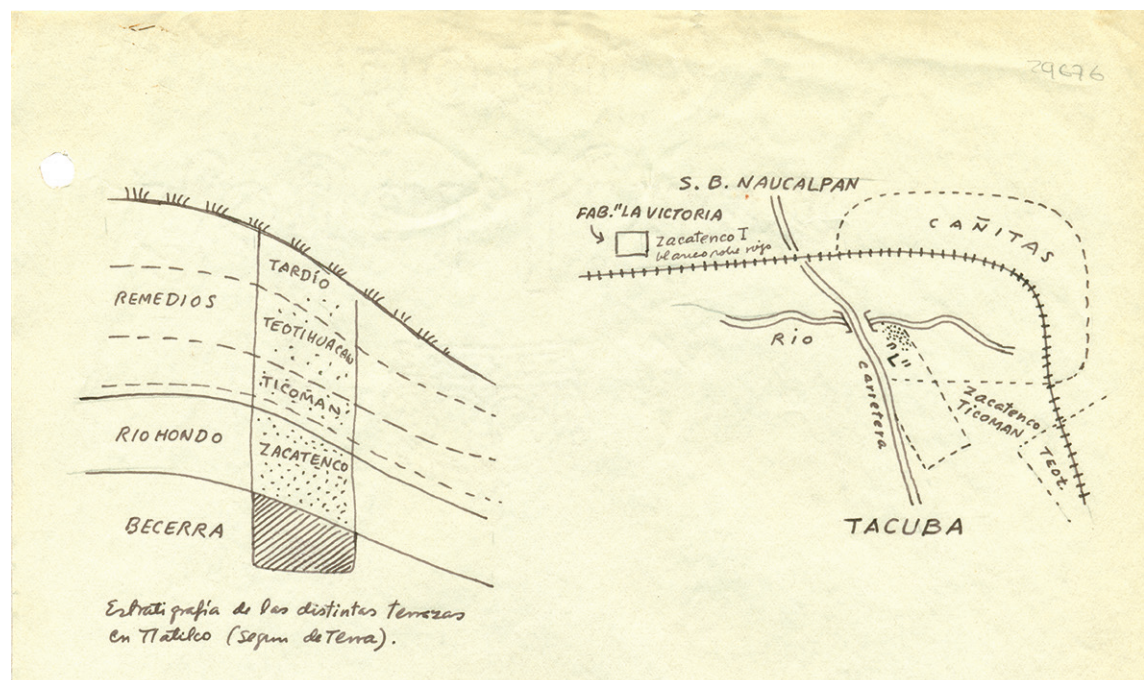

9. Miguel Covarrubias, Tlatilco. Estratigrafia de las distintas terrazas en Tlatilco, 1942-1949 (posiblemente 1943), tinta sobre papel. Archivo Miguel Covarrubias. Sala de Archivos y Colecciones Especiales, Dirección de Bibliotecas, Universidad de las Américas, Puebla.

Por una parte, en varios documentos Covarrubias y Moedano piden hablar de "cultura media" para evitar la apelación de "cultura arcaica" que, les parece, obstaculiza la concepción de una etapa anterior, muy probable.

Por otro lado, y de manera quizás contradictoria, Covarrubias entra en contacto con dos formas de trabajo que cambiarán su perspectiva. Una ya la conoce — sabemos que fue dibujante para los proyectos de Manuel Gamio y Franz Boas - y la otra no. La primera son los catálogos dibujados de cerámica, lo que Moedano llama "análisis tepalcatológico", que abundan en su archivo. ${ }^{41} \mathrm{La}$ segunda, tal vez la más interesante, son los frecuentes diagramas que Moedano dibujaba, a veces firmándolos, en papel milimétrico (fig. 8). Lo que esos

4I. Miguel Covarrubias, Vasijas, dibujo 49, diseños de formas diferentes: ollas, cántaros, botellones, tazones, cajetes, platos, vasos, copas, trípodes, 1947-1949, lápiz sobre papel. Archivo Miguel Covarrubias. Sala de Archivos y Colecciones Especiales, Dirección de Bibliotecas, Universidad de las Américas, Puebla.

Accesible en línea, ítem 29535: http://catarina.udlap.mx/xmLibris/projects/covarrubias/browse/ item.jsp?key=amc_tlatilco_ceramica_dibujos_fotografias_y_notas_38.xml\&id=tlatilco_ceramica_dibujos_fotografias_y_notas 
DOI: https://doi.org/10.22201/iie.18703062e.2020.Suplemento.2708

I80

RENATO GONZÁLEZ MELLO

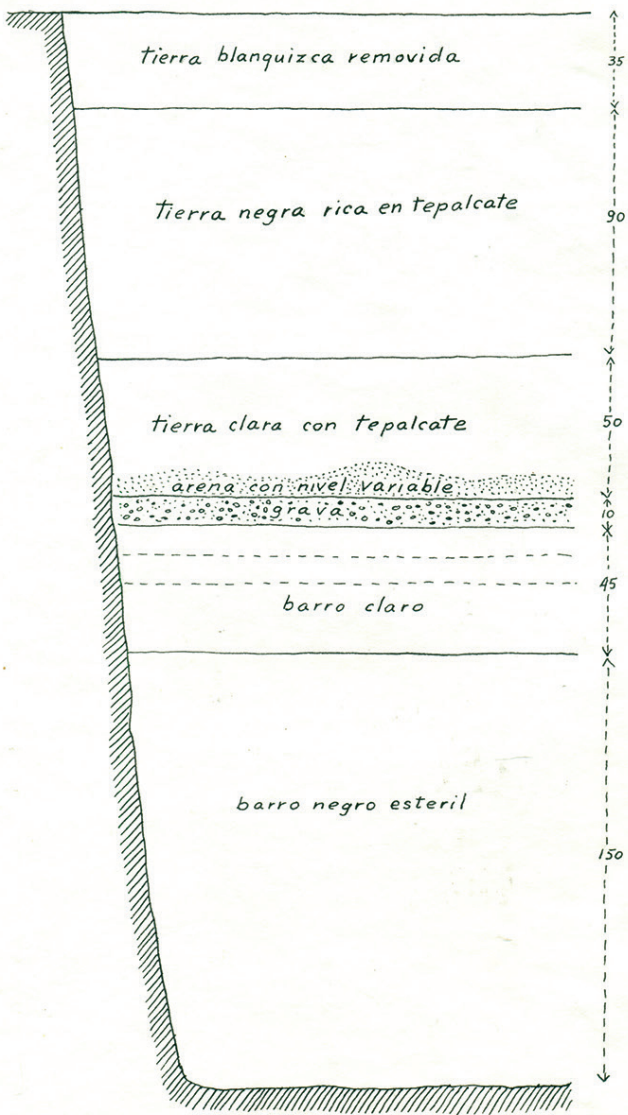

TLATILCO

Estructura del Terreno

en el agujero $g$

Io. Miguel Covarrubias, Tlatilco. Estructura del terreno en el agujero g, 1942-1949

(posiblemente 1943), tinta sobre papel. Archivo Miguel Covarrubias. Sala de Archivos y Colecciones Especiales, Dirección de Bibliotecas, Universidad de las Américas, Puebla. 
diagramas muestran son los registros de una excavación sistemática: qué se encontró en qué nivel; qué tipo de tierra corresponde a qué estrato (fig. 9). ${ }^{42}$

La estratigrafía de estos arqueólogos es más bien catastrofista, pues supone que las capas de tierra definen épocas que pueden definirse con nitidez, y que reemplazan integralmente a la época que las precede. Recordemos que al comenzar el siglo XIX, la geología cambió dramáticamente con el trabajo de William Smith y otros estudiosos, que mediante el estudio de los fósiles imaginaron estratos que traslapaban, y no sólo se superponían sobre la tierra. ${ }^{43}$ A pesar de aquella revolución, la estratigrafía de los arqueólogos se parece al catastrofismo geológico. Esto privilegia una representación gráfica de un tiempo lineal, pero no continuo: lleno de interrupciones. Los esquemas de Moedano incluyen registros de distintos tipos de tierra, fotografías de la excavación por etapas y complejos diagramas cronológicos que hacen, a la vez, un inventario de los hallazgos (fig. 8).

El problema, para Covarrubias, era reunir los hallazgos más antiguos con los más recientes. Ansioso de una explicación, o por lo menos de un relato distinto al de la estratigrafía, Covarrubias entendió la necesidad de contar con un diagrama para dialogar con sus nuevos colegas, los arqueólogos. En un informe que puede fecharse alrededor de 1942, trató de organizar sus ideas:

Todos éstos y muchos otros puntos de vista paralelos, muestran una muy interesante unidad de características culturales, que muy posiblemente indique un origen cultural, si no es que racial, en común, o por lo menos un desarrollo relacionado y simultáneo, tal vez la existencia de un complejo cultural muy viejo que puede llamarse "arcaico-olmeca", centrado alrededor del culto del tigre y manifiesto en excelentes jades y figurillas huecas en barro del tipo "tiger-baby" [...]

Estos misteriosos "hombres-tigre" pueden proveer la relación entre la etapa primitiva "arcaica" y la transición hacia culturas más tardías. Incluso es posible que este estilo "olmeca-tigre" se desarrollara en algún lugar del México tropical, tal vez en el Istmo de Tehuantepec (La Venta), del primitivo y "arcaico", y continuara

42. Revisé los siguientes expedientes: Miguel Covarrubias, "Tlatilco cerámica. Fotos, notas y dibujos"; "Tlatilco. Entierros/estratigrafía. Fotos y dibujos"; "Tlatilco exploraciones. Fotos, docs. y mapas"; "Tlatilco: varios"; "Tlatilco: notas"; "Tlatilco: informe de la Ia temporada", Archivo Miguel Covarrubias, Universidad de las Américas, Puebla (en adelante udLAP).

43. D. R. Oldroyd, Thinking about the Earth: A History of Ideas in Geology (Londres: Athlone, I996), I08-30. 
DOI: https://doi.org/10.22201/iie.18703062e.2020.Suplemento.2708

I82

RENATO GONZÁLEZ MELLO

THE EARLY HORIZON

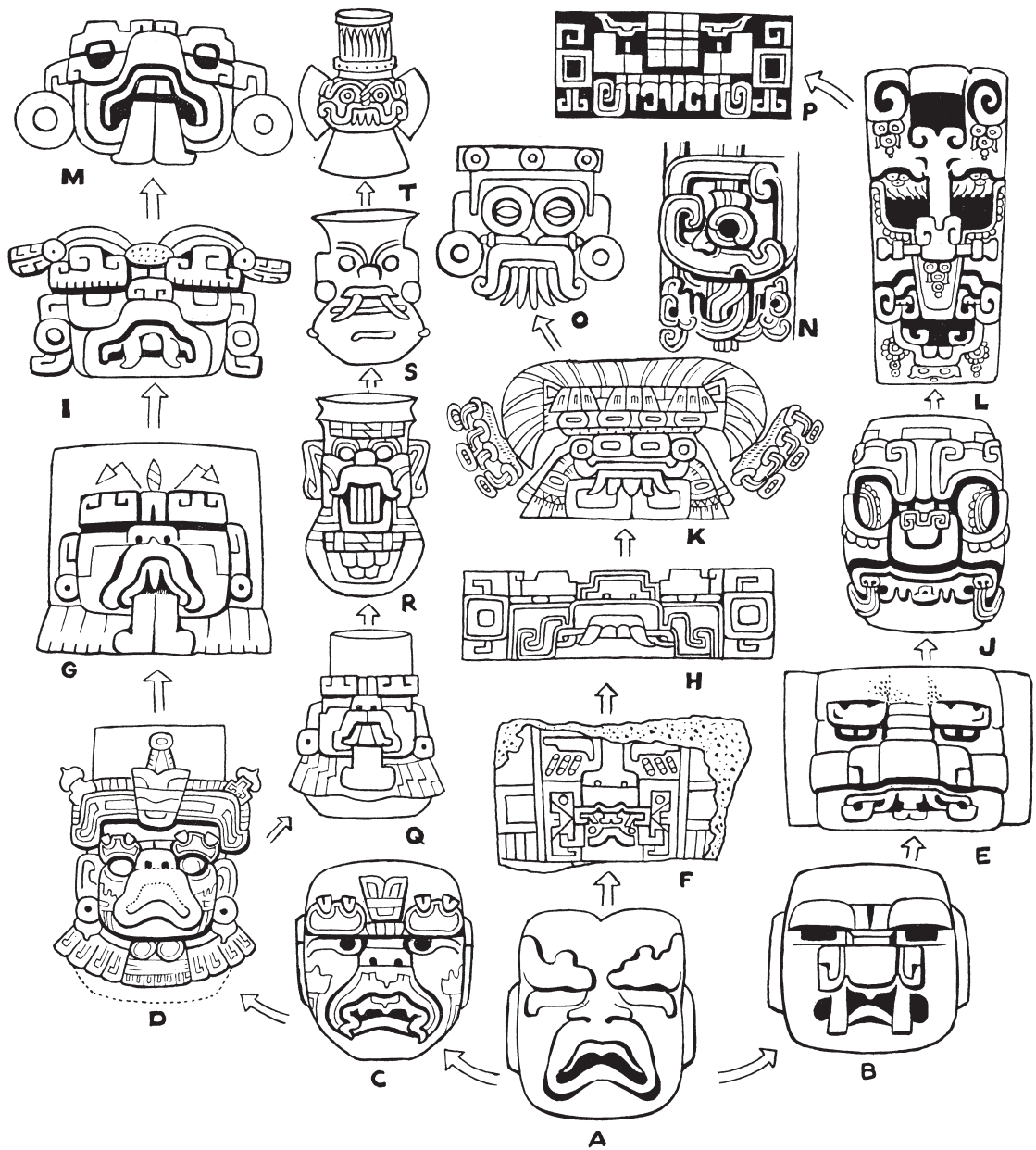

II. Miguel Covarrubias, “Chart showing 'Olmec' influence on evolution of the jaguar mask into rain gods (Chaac, Tajín, Tlaloc, Cosijo) and of rain-god vase (Early Monte Albán, Teotihuacán, Aztec)", ca. 1957, tomado de Miguel Covarrubias, Indian Art of Mexico and Central America (Nueva York: Knopf, 1957), 62, fig. 22. 


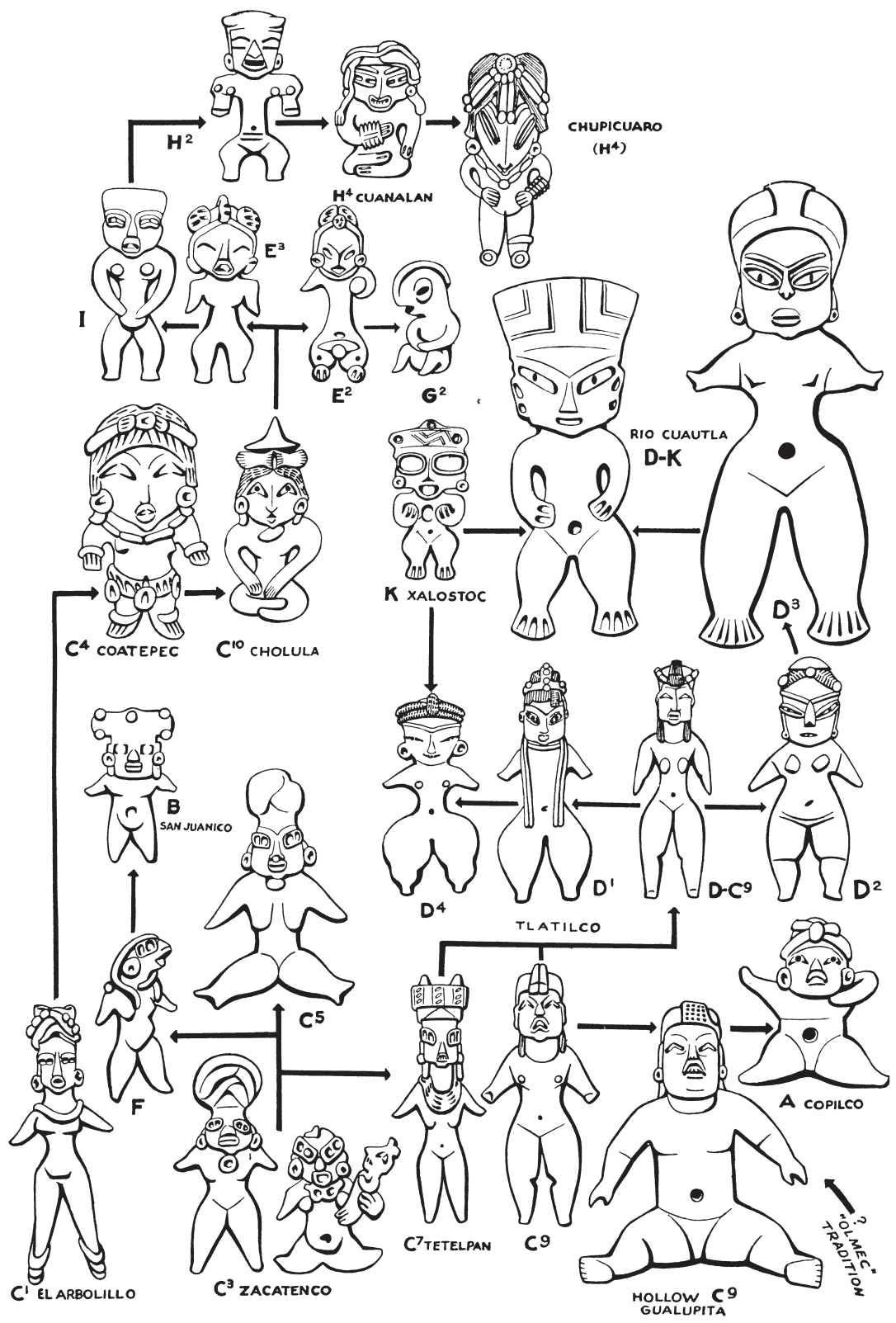

I2. Miguel Covarrubias, "Chart of interrelations among Pre-Classic clay figurine types", $c a$. 1957, impreso, tomado de Miguel Covarrubias, Indian Art of Mexico and Central America (Nueva York: Knopf, 1957), 29, fig. 8. 
evolucionando y extendiéndose hacia los cuatro vientos y resultando en las grandes culturas maya, tolteca, zapoteca y totonaca" (fig. II). ${ }^{44}$

\section{El diagrama de flujos}

Las lagunas y saltos lógicos, las contradicciones y ambivalencias en esta formulación eran demasiadas y requirieron de un largo proceso para articularse en su forma definitiva. En 1946, Covarrubias publicó en Cuadernos Americanos el diagrama que sería su contribución definitiva al conocimiento de las culturas de Mesoamérica (fig. II). ${ }^{45}$ Aventurándose mucho más lejos que la apreciación formal del "estilo olmeca", dibujó un sistema de fuerzas y recorridos que mostraba las transformaciones de la máscara de jaguar, desde la escultura del horizonte preclásico hasta las figuras que estuvieron en boga entre los aztecas en vísperas de la conquista. ${ }^{46}$

Este diagrama es la representación de un conjunto de disyunciones. Uno se pregunta por qué, si su propósito explícito era refundir un conjunto de objetos en una sola categoría: el estilo olmeca. Pero si algo importa en esta representación es que no muestra la convergencia de caracteres, sino la naturaleza divergente y más bien complicada de cualquier tipo. Parafraseando a Edward Tufte, podemos pensar que las diferencias entre las imágenes son unidas por un sistema de flechas que no tiene, entre sí, mayor diferencia, estableciendo algo así como un campo uniforme y no conflictivo del cambio histórico, un mero sistema formal de sucesiones. 47

El diagrama se parece mucho a otros esquemas que había dibujado, como "El árbol del arte moderno, sembrado hace sesenta años" (de nuevo un árbol), ${ }^{48}$ una caricatura que apareció en junio de 1933 en Vanity Fair, y muy probable-

44. Covarrubias, “Tlatilco: notas", UdLAP.

45. Véase supra n. 4I.

46. Covarrubias, "El arte 'olmeca' o de La Venta", I68.

47. Edward Rolfe Tufte, Beautiful Evidence (Cheshire, Connecticut: Graphics Press, 2010), 70.

48. Miguel Covarrubias, The Tree of Modern Art, mayo de 1933, impreso, en Vanity Fair, Nueva York, mayo de 1933 .

Una acuarela, aparentemente realizada a partir del dibujo publicado en la revista y prácticamente idéntica se encuentra en "The Tree of Modern Art, Planted 6o Years Ago". David Rumsey, Historical Map Collection, catálogo 8638.00o. Puede consultarse en línea en http://www.davidrumsey.com/ luna/servlet/detail/RUMSEY 8 I 269030 90043I27:The-Tree-of-Modern-Art,-Planted-60- 
mente el antecedente del famoso diagrama de Alfed Barr sobre el desarrollo del arte abstracto, de $1936.4^{9}$ Como lo dice Griselda Pollock, que en esto sigue a Meyer Schapiro, en este artefacto gráfico "el movimiento transcurre, conectado por flechas en una sola dirección que indican influencia y reacción. Sobre cada movimiento preside el nombre de un artista"..$^{\circ}$ Hasta qué punto el diagrama se utilizaba como instrumento para organizar un saber, se puede entender por un pentimento. Covarrubias dibujó una versión del diagrama de la máscara, quizás el primer borrador, en papel cuadriculado. Ahí, en el centro del sistema de flechas y máscaras, había incluido en una columna central una figura que, en la versión publicada, fue desplazada hacia el margen derecho. Es muy posible que su motivo haya sido la claridad de la argumentación: la figura desplazada, en la que la máscara de jaguar aparecía de perfil, difuminaba la contundente sucesión de máscaras vistas frontalmente. ${ }^{\text {II }}$

Como un instrumento para "normalizar [...] un conjunto de prácticas particular y con identidad de género", ${ }^{52}$ el diagrama elaborado en 1936 por Alfred Barr para la exposición Cubism and Abstract Art hace un intento de mostrar un fondo continuo, supuestamente neutral, para la organización de fuerzas que darían cuenta de la existencia de dos tendencias en el arte abstracto: geométricas y no geométricas. En ambos diagramas, flechas o ramas se extienden de un lado al otro. Las ramas principales en el Árbol del arte moderno de Covarrubias están trenzadas, en tanto que una flecha va del cubismo a Dadá en el esquema de Barr. Como contraste, el diagrama de la máscara de jaguar no permite ningún intercambio así, y prefiere señalar desarrollos exclusivos de diferentes

49. Astrit Schmidt-Burkhardt, Maciunas' Learning Machines: From Art History to a Chronology of Fluxus (Detroit: Gilbert and Lila Silverman Fluxus Collection in association with Vice Versa, Berlin, 2003), 24-28. Véase la imagen en Alfred Barr, Cubism and Abstract Art, 1936, impreso, camisa de la portada (Nueva York: Museum Of Modern Art). Disponible en línea: https://www.moma.org/documents/moma_catalogue_2748_300o86869.pdf

50 Griselda Pollock, Vision and Difference: Femininity, Feminism and the Histories of Art (Londres: Routledge, 1988), 50.

5I. En la reflexión sobre este pequeño cambio, me ayudó mucho la opinión del Dr. Erik Velásquez, a quien agradezco su generosa atención. Véase la imagen en Miguel Covarrubias, Diagrama de Miguel Covarrubias ilustrando el origen y evolución del dios de la lluvia mesoamericano, s.f., lápiz y tinta sobre papel, número 31189, Archivo Miguel Covarrubias, UdLAP.

Accesible en línea, ítem 31189: http://catarina.udlap.mx/xmLibris/projects/covarrubias/ browse/item.jsp?key=amc_exposicion_udlap_carpeta_iii_caricaturas_fotografias_y_notas_I7. xml\&id=exposicion_udlap_carpeta_iii_caricaturas_fotografias_y_notas

52. Pollock, Vision and Difference, 50. 
regiones y culturas en el territorio del que habla con naturalidad como "Mesoamérica”. Esto último es notable, ya que semejante topónimo había aparecido en un artículo de Paul Kirchoff apenas en 1943, y era solamente un inventario de rasgos comunes a toda esa región cultural — no era, pues, un sistema para distinguir una cultura de otra, sino lo contario. ${ }^{53}$

Covarrubias publicó otro diagrama en Indian Art of Mexico and Central America, para mostrar "las relaciones entre los tipos de las figurillas preclásicas" (fig. I2). ${ }^{54}$ Un diagrama mucho más complejo, mostrando dos caminos independientes uno del otro y un resultado circular en figurillas de Tlatilco y Xalostoc. Ya que me he referido al diagrama de Barr, ${ }^{55}$ quisiera señalar una diferencia adicional con el diagrama del jaguar. En lugar de nombrar las corrientes, como lo hizo en El árbol del arte moderno, y como era imposible incluir los nombres de los artistas, como lo había hecho Barr, Covarrubias decidió incluir las imágenes para subrayar la semejanza entre distintas iteraciones del tipo. Seguramente lo hizo por motivos pedagógicos.

Implícita en el dibujo, la noción de "estilo" que había propuesto con Alfonso Caso en 1942. El diagrama era una herramienta para desplegar una noción de "estilo" bastante moderna. Una noción formalista, en el registro arqueológico, que hacía visibles las implicaciones de esta idea, pero sobre todo su ambivalencia ante la historia. Sin embargo, creo que el propio diagrama responde a las críticas que se les hicieron en Tuxtla Gutiérrez, y a las contradicciones propias del concepto.

Como lo dijo Meyer Schapiro, la tabla de Barr separaba del arte moderno casi cualquier proceso político o social. ${ }^{56}$ Era una herramienta mnemónica para interactuar con la sala de exhibición, con la lectura del catálogo y para permitir la comparación entre distintas obras. ${ }^{57}$ Por el contrario, la inserción de los dibujos de las máscaras en el diagrama de Covarrubias le permitía funcionar

53. Paul Kirchhoff, "Mesoamérica. Sus límites geográficos, composición étnica y caracteres culturales”, Acta Americana I (1943): 92-I07. Para una historiografía crítica de esta noción, véase Eduardo Matos Moctezuma, "Mesoamérica”, en Historia antigua de México, ed. Linda Manzanilla y Leonardo López Luján (México: Consejo Nacional para la Cultura y las Artes/ Universidad Nacional Autónoma de México: M.A. Porrúa, 1994), 49-73.

54. Miguel Covarrubias, Indian Art of Mexico and Central America (Nueva York: Knopf, 1957), 29.

55. Pienso en un conjunto de estudios críticos que van desde Serge Guilbaut, De cómo Nueva York robó la idea de arte moderno (Madrid: Mondadori, 1990); hasta Pollock, Vision and Difference.

56. Pollock, Vision and Difference, I8-19.

57. Schmidt-Burkhardt, Maciunas' Learning Machines, 388. 
con independencia de cualquier contexto. Es significativo que, para cuando se reprodujo en Indian art of Mexico and Central America, no incluyera la leyenda escrita de la ilustración..$^{58}$ Esta operación es objeto de debate hasta la actualidad. Así Beatriz de la Fuente señaló en, I. ed la Primera Mesa Redonda (contemporánea) sobre los olmecas: "[...] no hay, a la fecha, fundamento mayor ni suficientes apoyos para afirmar que los grupos humanos creadores de las obras asignadas al 'estilo olmeca' corresponden a un mismo pueblo, que compartieron una misma lengua y las mismas creencias". 59

Este animado debate continúa hasta la fecha y López Hernández señala que la actual Sala Olmeca del Museo Nacional de Antropología e Historia ya no se refiere a la "cultura madre". ${ }^{60}$

\section{La raza y la figura}

Después de la discusión y críticas que plantearon Comas, Rubín de la Borbolla y otros en la mesa redonda de Tuxtla Gutiérrez, en 1942, llama la atención que Covarrubias y Moedano hayan comparado otra vez las figuras con los tipos raciales, usando nociones que, a la mitad de la Segunda Guerra Mundial, se estaban volviendo muy problemáticas. Las notas redactadas hacia 1942 son a este respecto reveladoras:

A juzgar por las figurillas, había una gran variedad de tipos viviendo juntos o, por lo menos, las figurillas se hacían de bajo una variedad de tradiciones estéticas simultáneas, de las que la más notable son los creadores refinados de las figurillas tipo $\mathrm{D}$, con el

58. Covarrubias, Indian Art of Mexico and Central America, 62.

59. Beatriz de la Fuente, “¿Puede un estilo definir una cultura?”, en Olmeca: balance y perspectivas: Memoria de la Primera Mesa Redonda, ed. María Teresa Uriarte y Rebecca B. González Lauck (México: Universidad Nacional Autónoma de México-Instituto de Investigaciones Estéticas/ Consejo Nacional para la Cultura y las Artes/Instituto Nacional de Antropología e Historia/ Fundación Arqueológica del Nuevo Mundo/Universidad Brigham Young, 2008), 30; También es muy interesante la crítica de Graham, "Leyendo el pasado: la arqueología olmeca y el curioso caso de la estela C de Tres Zapotes", Uriarte y Lauck, Olmeca: balance y perspectivas: memoria de la Primera Mesa Redonda, 39-63. López Hernández, En busca del alma nacional, 344, discute las ideas expresadas por la propia Beatriz de la Fuente, "Toward a Conception of Monumental Olmec Art", en The Olmec and their Neighbors. Essays in Memory of Matthew W. Stirling, Elizabeth P. Benson, ed. (Washington, D.C.: Dumbarton Oaks Research Library and Collections, 1980), 83-94. 6o. López Hernández, En busca del alma nacional, 365-366. 
estilo contrastante y la apariencia física y vestido totalmente diferentes de los tipos C, B, F. Hay predominancia de rasgos finos, casi un tipo hermoso con ojos largos e inclinados, narices y bocas pequeñas, pero hay otros con rasgos rudos y brutales, $\mathrm{y}$ algunos tienen narices largas y aguileńas. Hay todos los tipos raciales (caucasoide, mongoloide e incluso negroide, mostrando que no había nada parecido a la unidad racial en el tipo "arcaico". ${ }^{6}$ I

México fue uno de los países que primero cobraron conciencia del Holocausto, en buena medida a través de las imágenes del Taller de Gráfica Popular. ${ }^{62}$ Esta confusión entre "raza" y "estilo" pudo haberse vuelto cada vez más problemática con el paso de los años. Por añadidura, y por razones que no pude precisar, al finalizar la década del cuarenta aparece un nuevo colaborador en el proyecto de excavación de Tlatilco: es Daniel Rubín de la Borbolla, que en la Mesa Redonda de 1942 había discutido con rigor la confusión de categorías raciales y estilísticas.

Sería largo argumentar, y no es éste el momento, las ramificaciones de este pensamiento. Insisto: hay en la invención del estilo olmeca, y de los olmecas, un interés que originalmente es literario; sin embargo, en la medida en que avanzan las excavaciones en Tlatilco — pero también la historia del siglo xxlos tópicos de la idolatría, el deseo, la regresión evolutiva y la raza se vuelven cada vez más problemáticos.

Uno de los orígenes de este conjunto de obsesiones es fácil de identificar: se trata del modernismo, y de manera más concreta, se trata de José Juan Tablada. El poeta mexicano había sido crucial para facilitar la emigración de Covarrubias a Nueva York. Como ocurrió en otros casos, notablemente en el de José Clemente Orozco, la producción plástica de Covarrubias registra algunas preocupaciones de su amigo y, en buena medida, mentor. Los dos se concibieron como embajadores culturales. Entre regiones distintas, sí; pero también entre épocas diferentes. Tablada es un protagonista del fin del modernismo literario, como lo recuerda Octavio Paz, quien además asegura que "de su pasado modernista no se conserva ninguna huella visible". ${ }^{63}$ Seguramente tiene razón en lo que toca a la poesía de Tablada, pero discrepo de Paz en que no se con-

6r. Covarrubias, "Tlatilco: notas", I.

62. Natalia de la Rosa, "Épica escenográfica: David Alfaro Siqueiros: acción dramática, trucaje cinemático y la construcción del realismo alegórico en la guerra (1932-1945)" (Doctorado en Historia del Arte, unam, Posgrado en Historia del Arte, 2016) (Facultad de Filosofía y Letras), i40-44.

63. Octavio Paz, Las peras del olmo (Barcelona: Seix Barral, I974), 6I-62. 
servara "ninguna huella". Tablada tenía mucha conciencia sobre las huellas y restos, y de alguna manera era el principal responsable de su propia arqueología.

La novela La resurrección de los ídolos es una especie de enciclopedia de los años veinte en México, entre otras cosas por sus recursos narrativos: saltos en el tiempo e introducción de textos externos al relato. También es un catálogo de las obsesiones de la narrativa decadentista: las ansiedades de la virilidad, el fetichismo, las figuras femeninas dúplices. Los personajes son licuados de distintos actores de la pequeñísima escena cultural mexicana: Sylvanus G. Morley, José Clemente Orozco, David Alfaro Siqueiros, Concha Michel y Lupe Marín. Hay un personaje al que le dicen, como a Miguel Covarrubias, "el Chamaco". El argumento central del relato es, como lo indica su título, el regreso de los ídolos, que emergen con vida del subsuelo telúrico en medio de terremotos para enfrentarse con Jesús. Lo más interesante para nuestros fines es la conferencia del profesor Neville (¿Morley? ¿Franz Boas?), que prepara "vistas de linterna" con fotografías de sus hallazgos arqueológicos mientras el pintor Amadeo (¿David Alfaro Siqueiros? ¿Orozco? ¿Covarrubias? ¿Adolfo Best Maugard? ¿Amado de la Cueva?) prepara una ilustración.

Amadeo había pintado un cartel a colores, ensayo de síntesis de las fuerzas cósmicas y espirituales que los ídolos representaban.

[...]

- iHombre, carramba, Amadeo! En ese cartel cubista que usted pintó no se ven los ídolos como son... Usted pintar la casa de Huitzilopochtli como con peste bubónica y Tláloc muerde a Xochiquetzal, que era Venus y Minerva, y Coatricue parece un jaguar que va a saltar... ¿Y sabe usted?, entrecerrando los ojos o viendo el cartel de lejos, todo parece como una enorme calavera. ${ }^{64}$

En el relato se dividen con precisión las tareas del arqueólogo y el artista: —Pero... —objetó Neville—, todo está desfigurado...

-Claro, la reproducción exacta la verá el público en las proyecciones fotográficas de usted... Mi cuadro, como todas las pinturas verdaderas, es una distorsión...

Pero manteniéndome en los límites de los años veinte, cuando el diálogo entre Covarrubias y Tablada es más intenso, me parece muy importante uno

64. José Juan Tablada, "La resurrección de los ídolos”, en José Juan Tablada, ed. Antonio Saborit (Ciudad de México: Ediciones Cal y Arena, 2008), 543. Se ha respetado la ortografía del original. 
de los caligramas en Li-po y otros poemas. Se trata de "Otros poemas ideográficos", una especie de catálogo de sus propias obras. La lista incluye varios títulos, indicando los años (probablemente los que corresponden a su creación) y unidos por flechas dibujadas a mano. Abajo, manuscrito, un haikai:

\author{
Ahuyenten estas flechas \\ las sombras de la pata del oso \\ sobre el panal de mis abejas...65
}

Este dispositivo era una especie de amuleto para evitar alguna intervención indeseada en el pasado: una manera de conjurar la resurrección de ídolos personales que eran, para Tablada, los del simbolismo, el decadentismo y el modernismo. Su joven amigo pintor, Miguel Covarrubias (a diferencia de José Clemente Orozco) no había vivido la transición entre el mundo cultural de Misa Negra y "el eterno presente de las vanguardias", como dice Antonio Saborit. ${ }^{66}$

En cualquier caso, y como ha argumentado de manera muy extensa Fausto Ramírez, ${ }^{67}$ en las propuestas mexicanas del siglo xx es imposible obviar las contribuciones del modernismo; tal vez porque la estética de la vanguardia no siempre se adoptó, como lo hizo Tablada, en forma radical. En esto también, la reflexión de Tablada es acerca de los cambios en la antigüedad; pero el origen de esa reflexión está en los cambios, muy dramáticos, que vivieron él mismo y sus contemporáneos. ثे

Nueva York, 2007; Coyoacán, 2019.

65. José Juan Tablada, "Otros poemas ideográficos”, Li-Po y otros poemas (Caracas: s.e., I920), 23. En Rodolfo Mata, "José Juan Tablada- Letra e imagen”, José Juan Tablada-Letra e imagen, consultado el 30 de enero de 2018 , http://www.tablada.unam.mx/poesia/lipo/li-poI2.htm.

66. Tablada, José Juan Tablada, II.

67. Fausto Ramírez, Modernización y modernismo en el arte mexicano (Ciudad de México: Universidad Nacional Autónoma de México-Instituto de Investigaciones Estéticas, 2008).

N.B. Una versión preliminar de este ensayo se presentó en el University Seminar on the Arts of Africa, Oceania, and the Americas de la Universidad de Columbia, y se escribió gracias a un apoyo de la Bernard Laroque Tinker Foundation otorgado por dicha universidad. Un agradecimiento especial al Fideicomiso de los Museos de Diego Rivera y Frida Kahlo y a Hilda Trujillo. A Daniel Vargas Parra, Federico Navarrete y Haydée López Hernández. Asimismo, gracias a los lectores anónimos que hicieron acertadas correcciones - y objeciones de fondo- a este artículo. 